\title{
The Specificity of Downstream Signaling for $A_{1}$ and $A_{2 A} R$ Does Not Depend on the C-Terminus, Despite the Importance of This Domain in Downstream Signaling Strength
}

\author{
Abhinav R. Jain ${ }^{1}{ }^{(\mathbb{D}}$, Claire McGraw ${ }^{1}$ and Anne S. Robinson ${ }^{1,2, *(\mathbb{C}}$ \\ 1 Department of Chemical and Biomolecular Engineering, Tulane University, New Orleans, LA 70118, USA; \\ abhinavrjain@gmail.com (A.R.J.); clairemcgraw90@gmail.com (C.M.) \\ 2 Department of Chemical Engineering, Carnegie Mellon University, Pittsburgh, PA 15213, USA \\ * Correspondence: anne.robinson@cmu.edu; Tel.: +1-412-268-7673
}

Received: 17 November 2020; Accepted: 9 December 2020; Published: 13 December 2020

\begin{abstract}
Recent efforts to determine the high-resolution crystal structures for the adenosine receptors $\left(A_{1} R\right.$ and $\left.A_{2 A} R\right)$ have utilized modifications to the native receptors in order to facilitate receptor crystallization and structure determination. One common modification is a truncation of the unstructured C-terminus, which has been utilized for all the adenosine receptor crystal structures obtained to date. Ligand binding for this truncated receptor has been shown to be similar to full-length receptor for $\mathrm{A}_{2 \mathrm{~A}} \mathrm{R}$. However, the C-terminus has been identified as a location for protein-protein interactions that may be critical for the physiological function of these important drug targets. We show that variants with $\mathrm{A}_{2 \mathrm{~A}} \mathrm{R} C$-terminal truncations lacked cAMP-linked signaling compared to the full-length receptor constructs transfected into mammalian cells (HEK-293). In addition, we show that in a humanized yeast system, the absence of the full-length C-terminus affected downstream signaling using a yeast MAPK response-based fluorescence assay, though full-length receptors showed native-like G-protein coupling. To further study the G protein coupling, we used this humanized yeast platform to explore coupling to human-yeast G-protein chimeras in a cellular context. Although the $C$-terminus was essential for $G \alpha$ protein-associated signaling, chimeras of $A_{1} R$ with a $C$-terminus of $A_{2 A} R$ coupled to the $A_{1} R$-specific $G \alpha$ (i.e., $G \alpha i 1$ versus $G \alpha s$ ). This surprising result suggests that the C-terminus is important in the signaling strength, but not specificity, of the $G \alpha$ protein interaction. This result has further implications in drug discovery, both in enabling the experimental use of chimeras for ligand design, and in the cautious interpretation of structure-based drug design using truncated receptors.
\end{abstract}

Keywords: yeast pheromone response; $\mathrm{G}$ protein-coupled receptors; adenosine receptor; C-terminus; G protein; receptor chimera

\section{Introduction}

G-protein coupled receptors (GPCRs) are the largest family of membrane proteins, with over 800 genes in humans [1]. GPCRs are characterized by seven alpha-helical transmembrane domains and bind to extracellular molecules, activating downstream signaling responses inside the cell. GPCRs are found in eukaryotic systems from yeast to mammals and aid in essential functions; in yeast, they mediate the mating pheromone response pathway [2]. Because of their membrane localization and the ability to produce intracellular changes, they are desirable targets for therapeutics, with approximately $40 \%$ of drugs on the market targeting these receptors [3,4]. 
Biophysical characterization and high-resolution structure determination are routinely used for GPCR drug design and discovery and require heterologous expression and purification [5-7]. Most receptors are not expressed in heterologous systems at $\mathrm{mg} / \mathrm{L}$ concentrations required for this structural characterization [8]. Therefore, additional strategies like truncations to remove unstructured regions, thermostabilization via point mutations, and chimeras with thermostable proteins have been utilized to improve expression and crystallization (for example, see modifications for adenosine receptors in Table 1). However, these modifications may change receptor activity and function. 
Table 1. List of adenosine receptor high-resolution structures. Agonists are underlined.

\begin{tabular}{|c|c|c|c|c|c|c|c|c|c|}
\hline \multirow{2}{*}{ Receptor } & \multirow{2}{*}{ Year } & \multirow{2}{*}{ Resolution (Å) } & \multirow{2}{*}{ Expression Host } & \multirow{2}{*}{ Ligand } & \multicolumn{4}{|c|}{ Modification } & \multirow{2}{*}{ Reference } \\
\hline & & & & & Chimera & Stabilization & Thermo-Stabilization & Truncation & \\
\hline \multirow{28}{*}{$A_{2 A} R$} & 2008 & 2.6 & S. frugiperda & ZM241385 & $\mathrm{x}$ & & & $\mathrm{x}$ & Jaakola et al. [9] \\
\hline & 2011 & 2.71 & S. frugiperda & UK-432097 & $x$ & & & $x$ & Xu et al. [10] \\
\hline & 2011 & $2.6-3$ & Trichoplusia ni & Adenosine; NECA & & & $x$ & $x$ & Lebon et al. [11] \\
\hline & 2011 & $3.3-3.6$ & S. frugiperda & Caffeine; ZM241385; XAC & & & $x$ & $x$ & Dore et al. [12] \\
\hline & 2012 & $2.7-3.1$ & P. pastoris & ZM241385 & & $x$ & & $x$ & Hino et al. [13] \\
\hline & 2012 & $3.27-3.34$ & S. frugiperda & Novel compounds & & & $x$ & $x$ & Congreve et al. [14] \\
\hline & 2012 & 1.8 & S. frugiperda & ZM241385 & $\mathrm{x}$ & & & $x$ & Liu et al. [15] \\
\hline & 2015 & 2.6 & Trichoplusia ni & CGS21680 & & & $x$ & $x$ & Lebon et al. [16] \\
\hline & 2016 & $1.72-2.2$ & Trichoplusia ni & ZM241385 and 4 novel compounds & $\mathrm{x}$ & & $x$ & $x$ & Segala et al. [17] \\
\hline & 2016 & 3.4 & Trichoplusia ni & NECA & $\mathrm{x}$ & $\mathrm{x}$ & & $\mathrm{x}$ & Carpenter et al. [18] \\
\hline & 2016 & $1.9-2.5$ & S. frugiperda & ZM241385 & $x$ & & & $x$ & Batyuk et al. [19] \\
\hline & 2017 & 3.5 & S. frugiperda & Novel compound & $\mathrm{x}$ & & & $x$ & Sun et al. [20] \\
\hline & 2017 & 3.2 & S. frugiperda & ZM241385 & $\mathrm{x}$ & & & $x$ & Martin-Garcia et al. [21] \\
\hline & 2017 & 2.8 & S. frugiperda & ZM241385 & $x$ & & & $x$ & Melnikov et al. [22] \\
\hline & 2017 & $2-2.8$ & Trichoplusia ni & Theophylline; caffeine; PSB36 & $x$ & & $x$ & $x$ & Cheng et al. [23] \\
\hline & 2017 & $1.7-2.14$ & Trichoplusia ni & ZM241385 & $x$ & & $x$ & $x$ & Weinert et al. [24] \\
\hline & 2018 & 2.35 & S. frugiperda & ZM241385 & $x$ & & $x$ & $x$ & Broecker et al. [25] \\
\hline & 2018 & 2.51 & P. pastoris & ZM241385 & $x$ & & & $\mathrm{x}$ & Eddy et al. [26] \\
\hline & 2018 & $1.87-3.1$ & Trichoplusia ni & $\begin{array}{l}\text { Theophylline, ZM241385, Vipadenant, LUAA47070, Tozadenant and } \\
2 \text { novel compounds }\end{array}$ & $x$ & & $\mathrm{x}$ & $x$ & Rucktooa et al. [27] \\
\hline & 2018 & $2.6-2.9$ & P. pastoris & $\underline{\text { UK-432097 }}$ & $x$ & & & $\mathrm{x}$ & White et al. [28] \\
\hline & 2018 & 4.11 & Trichoplusia ni & NECA & $x$ & $\mathrm{x}$ & & $x$ & Garcia-Nafria et al. [29] \\
\hline & 2019 & 4.2 & S. frugiperda & ZM241385 & $x$ & & & $x$ & Martin-Garcia et al. [30] \\
\hline & 2019 & 2.25 & S. frugiperda & ZM241385 & $x$ & & & $x$ & Shimazu et al. [31] \\
\hline & 2019 & 1.85 & S. frugiperda & ZM241385 & $x$ & & & $x$ & Ishchenko et al. [32] \\
\hline & 2020 & $1.92-2.13$ & Trichoplusia ni & Novel Ligands & $x$ & & $x$ & $x$ & Jespers et al. [33] \\
\hline & 2020 & 2 & S. frugiperda & ZM241385 & $x$ & & & $x$ & Lee et al. [34] \\
\hline & 2020 & 2 & Trichoplusia ni & AZD4635 & $x$ & & $\mathrm{x}$ & $x$ & Borodovsky et al. [35] \\
\hline & 2020 & $1.8-2$ & S. frugiperda & ZM241385 & $x$ & & & $x$ & Ihara et al. [36] \\
\hline \multirow{3}{*}{$A_{1} \mathbf{R}$} & 2017 & 3.2 & S. frugiperda & DU172 & $x$ & & & $x$ & Glukhova et al. [37] \\
\hline & 2017 & 3.3 & Trichoplusia ni & PSB36 & $x$ & & $\mathrm{x}$ & $x$ & Cheng, et al. [23] \\
\hline & 2018 & 3.6 & Trichoplusia ni & Adenosine and DU172 & $x$ & & & & Draper-Joyce et al. [38] \\
\hline
\end{tabular}


Adenosine receptors are a GPCR subfamily of four receptors $\left(A_{1} R, A_{2 A} R, A_{2 B} R\right.$ and $\left.A_{3} R\right)$ that recognize the natural ligand adenosine, an important energy metabolite [39,40]. Adenosine is produced in tissues under stressful conditions like ischemia or hypoxia or energy "demand-supply" imbalance [41,42]. All four adenosine receptor subtypes provide critical protection under stressful conditions and, therefore, are therapeutic targets for Parkinson's disease, Alzheimer's disease, cardiovascular diseases, and many others [43]. Multiple crystal structures of $\mathrm{A}_{2 \mathrm{~A}} \mathrm{R}$ have been resolved with bound agonists or antagonists (Table 1). All structures reported for the adenosine receptors contain a $C$-terminal truncation, except a recently published cryo-EM structure of $A_{1} R$ [38].

The $\mathrm{C}$-terminus of $\mathrm{A}_{1} \mathrm{R}$ is 34 amino acids long, whereas the $\mathrm{A}_{2 \mathrm{~A}} \mathrm{R} \mathrm{C}$-terminus is relatively long with 122 amino acids. The two crystal structures of $A_{1} R$ contain a truncation from residues 311 and 316. Most crystal structures of $A_{2 A} R$ contain a truncation from residue $316\left(A_{2 A} \Delta 316 R\right)$, corresponding to only 26 amino acids out of the 120 , or approximately $20 \%$ of the total $A_{2 A} R$ C-terminus. The long C-terminus of $\mathrm{A}_{2 \mathrm{~A}} \mathrm{R}$ has been hypothesized to be involved in receptor expression [44-46], interactions with other signaling partners [47,48], oligomerization [49] and receptor turnover [50,51]. However, previous studies have suggested that the $\mathrm{A}_{2 \mathrm{~A}} \Delta 316 \mathrm{R}$ has native-like signaling [52-54] and native-like ligand binding $[52,55]$. In addition, the absence of the canonical cysteine for palmitoylation (position 309) in $A_{2 A} R$ has been noted to potentially add flexibility to bind interaction partners [48]; however, the truncation does not appear to alter its desensitization or turnover, as the critical Thr298 is still present [52,56].

Receptor chimeras have been used traditionally to understand the role of the receptor domains in improving functional expression, ligand recognition, and G-protein coupling and specificity, and the ability to produce downstream signaling [46,57-60]. In our previous study [44], we created an adenosine $A_{1} / A_{2 A}$ receptor chimera to improve membrane localization and expression in yeast for $A_{1}$ receptor $\left(A_{1} R\right)$ variants and reported exceptional yields of the active receptor compared to parental $\mathrm{A}_{1} \mathrm{R}$ expressed in any host system to date. In that study, plasma membrane trafficking of $\mathrm{A}_{2 \mathrm{~A}} \mathrm{R}$ and $\mathrm{A}_{2 \mathrm{~A}} \Delta 316 \mathrm{R}$ were similarly efficient, while trafficking of the $\mathrm{A}_{1} / \mathrm{A}_{2 \mathrm{~A}} \mathrm{R}$ chimera was improved relative to wild-type $A_{1} R$, with resulting improvements in radioligand binding activity, as measured in whole cells [44].

Yeast shares many functionally exchangeable proteins involved in the GPCR signaling pathway with higher eukaryotes [2,61], has served as a useful microbial platform for rapid ligand screening and leads the development of orphan GPCRs [62]. The most researched GPCR-mediated pathway in yeast is responsive to the presence of peptide mating pheromones that regulate metabolism related to mating. Activated receptors catalyze dissociation of Gpa1, the yeast G protein, activating a mitogen-activated protein kinase (MAPK) cascade, which has been used as a unique platform to study human GPCR signaling [63]. In contrast, the presence of multiple GPCRs and G $\alpha$ proteins in native mammalian systems can confound the results from downstream signaling assays. Yeast provides a relatively simple and inexpensive platform without the complexities of multiple GPCRs, receptor promiscuity, and crosstalk that occurs in native mammalian hosts $[64,65]$.

Engineered yeast strains with modification to the native MAPK-based signaling pathway to report on ligand-mediated downstream signaling from human GPCRs (Figure 1A) were obtained both from the Broach laboratory [66] and the Dowell laboratory at GlaxoSmithKline [67]. In these yeast strains, the last five amino acids of native yeast $\mathrm{G} \alpha$ (Gpa1) were replaced with the last five amino acids residues from a human $\mathrm{G} \alpha$ to yield native-like GPCR-G $\alpha$ interactions. This replacement has been shown to be sufficient for coupling with many human GPCRs, including human $\mathrm{A}_{2 \mathrm{~A}} \mathrm{R}$, resulting in a native-like dose response and ligand binding order preference [67]. Because of structure-based drug discovery efforts that rely on truncated receptors for in silico screening, we investigated one of the key protein-protein interactions of the C-terminus, coupling to G-protein to activate downstream signaling by utilizing this engineered yeast pheromone response pathway. 


\section{A}

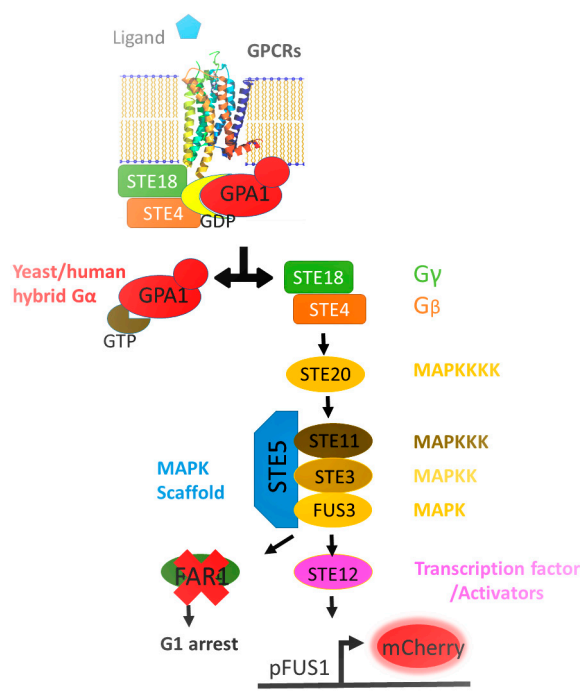

B

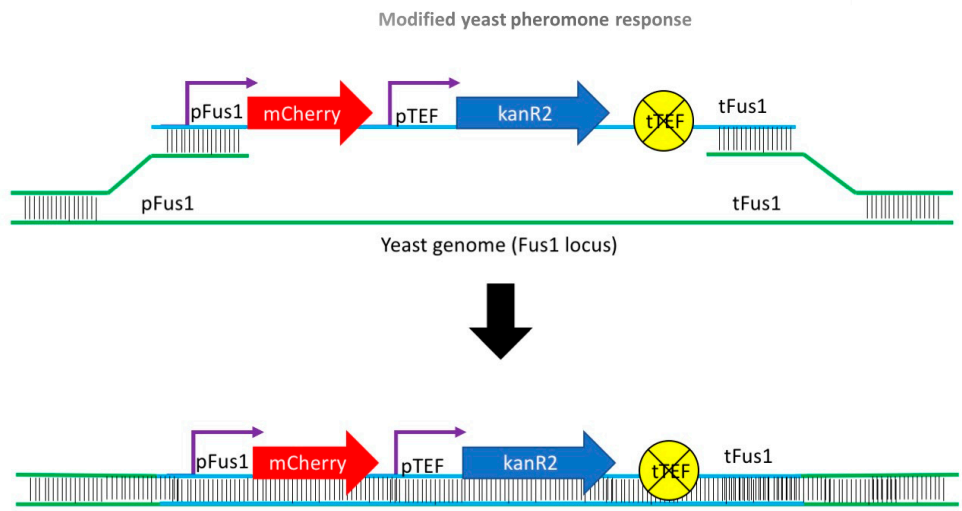

Figure 1. (A) Schematic of G-protein coupled receptors (GPCR)-mediated mitogen-activated protein kinase (MAPK) signaling cascade in yeast. In this engineered pheromone response signaling pathway, cells express a yeast/human chimeric G $\alpha$ protein to enable human GPCRs to couple with the yeast signaling pathway. Upon activation of downstream signaling, cells express mCherry fluorescent protein, which acts as an indirect measure of receptor activation. (B) Diagram represents homologous recombination approach used to include the mCherry gene along with the antibiotic resistance gene for clone selection within the Fus1 locus of yeast strains.

\section{Experimental Section}

\subsection{Materials}

Adenosine receptor ligands 5'-N-ethylcarboxamidoadenosine (NECA), N6 ${ }^{6}$-cyclopentyladenosine (CPA) and CGS21680 were purchased from Tocris (Minneapolis, MN, USA). Forskolin was obtained from Sigma-Aldrich (St. Louis, MO, USA). Precision Plus Protein Western C Standards was purchased from Biorad (Hercules, CA, USA). Human embryonic kidney cells (HEK-293, were obtained from ATCC (Manassas, VA, USA). Dulbecco's modified eagle medium (DMEM, 11995-065), Opti-MEM I reduced serum media (31985-070), fetal bovine serum (FBS, 16000-044), Lipofectamine 2000 transfection reagent (11668-019), RIPA buffer, Halt Protease and Phosphatase Inhibitor Cocktail, mammalian expression vectors (pCEP4) and Alexa 568-donkey anti-rabbit antibody (A10042) were obtained from Invitrogen Life Technologies (Carlsbad, CA, USA). The cAMP dynamic 2 kit was purchased from Cisbio US Inc. (Bedford, MA, USA). The mouse monoclonal $\mathrm{A}_{2 \mathrm{~A}} \mathrm{R}$ antibody was obtained from Santa Cruz Biotechnology (sc-32261, Dallas, TX, USA). The rabbit anti-GFP antibody (ab6556) and goat pAb to Mouse IgG HRP antibody (ab97265) were obtained from Abcam (Cambridge, MA, USA). 


\subsection{Strains and Culture Conditions}

E. coli strain $\mathrm{DH} 5 \alpha$ was used for amplifying yeast expression plasmids and mammalian expression vectors. E. coli was grown in Luria-Bertani media supplemented with $100 \mu \mathrm{g} / \mathrm{mL}$ ampicillin at $37^{\circ} \mathrm{C}$ at $250 \mathrm{rpm}$.

All yeast strains used in this study are summarized in Table 2. Yeast strains with modified pheromone response pathway and human-yeast chimeric G $\alpha$ proteins (Figure 1A) were obtained from the Broach laboratory [66] and Glaxo-Smith-Kline (GSK) [67]. These parental yeast strains were grown in YPD media ( $2 \%$ bacto peptone, $2 \%$ glucose, $1 \%$ yeast extract) and, depending on the fus 1 transformation, supplemented with $300 \mu \mathrm{g} / \mathrm{mL}$ hygromycin B or $200 \mu \mathrm{g} / \mathrm{mL}$ G418. Yeast expression plasmids were constructed using homologous recombination in S. cerevisiae strain BY4741 (MATa his $3 \Delta 1$ leu $2 \Delta 0$ met $15 \Delta 0$ ura3 $\Delta 0$ ) and were grown in synthetic media. The synthetic media (SD or SG) was comprised of $2 \%$ dextrose or galactose, respectively, $0.67 \%$ yeast nitrogen base, citrate buffer at $\mathrm{pH}$ 5.4 (4.2 g/L citric acid and $14.7 \mathrm{~g} / \mathrm{L}$ sodium citrate) and supplemented with amino acids and essential nutrients as described by Burke and colleagues [68]. Uracil was omitted from this media (SD-ura or SG-ura) to select for plasmid-containing cells. Yeast was grown in culture tubes and multiwell plates at $30^{\circ} \mathrm{C}$ at $275 \mathrm{rpm}$.

Table 2. List of yeast strains used.

\begin{tabular}{|c|c|c|c|}
\hline Yeast Strain & G Protein & Last 5 Amino Acids at C-Terminal & Equivalent Human G $\alpha$ \\
\hline MMY12, BY4741 & Gpa1 & KIGII ${ }^{\mathrm{COOH}}$ & GPA1 (yeast) \\
\hline MMY14 & Gpa1-G $\alpha q(5)$ & EYNLVCOOH & GNAQ, GNA11 \\
\hline MMY16 & Gpa1-Ga16(5) & EINLL $\mathrm{COOH}$ & GNA15, GNA16 \\
\hline MMY19 & Gpa1-G $\alpha 12(5)$ & DIMLQ ${ }^{\mathrm{COOH}}$ & GNA12 \\
\hline MMY20 & Gpa1-Ga13(5) & QLMLQ $^{\mathrm{COOH}}$ & GNA13 \\
\hline MMY21 & Gpa1-Ga14(5) & EFNLV $\mathrm{COOH}$ & GNA14 \\
\hline MMY22 & Gpa1-G $\alpha o(5)$ & GCGLYCOOH & GNAO \\
\hline MMY23, CY13393 & Gpa1-Gai1(5) & DCGLFCOOH & GNAI1, GNAI2, GNAT1, GNAT2, GNAT3 \\
\hline MMY24 & Gpa1-Gai3(5) & ECGLYCOOH & GNAI3 \\
\hline MMY25 & Gpa1-G $\alpha z(5)$ & YIGLC $\mathrm{COOH}$ & GNAZ \\
\hline MMY28, CY13399 & Gpa1-G $\alpha$ s(5) & QYELL $\mathrm{COOH}$ & GNAS, GNAL \\
\hline
\end{tabular}

Human embryonic kidney (HEK-293) cells were maintained in growth media containing DMEM with $10 \% \mathrm{FBS}$ at $37^{\circ} \mathrm{C}$ in a $5 \% \mathrm{CO}_{2}$ incubator. Transient transfections were performed by seeding cells on day 0 to be approximately $70 \%$ confluent on day 1 . On day 1 , cells were transfected using $10 \mu \mathrm{L}$ Lipofectamine 2000 reagent, and $1 \mu \mathrm{g}$ DNA in $2 \mathrm{~mL}$ Opti-MEM reduced serum media (per $25 \mathrm{~cm}^{2}$ flask). On day 2, the media was replaced by FBS supplemented DMEM media, and used for experimentation on day 3 , approximately $36 \mathrm{~h}$ post-transfection. The cAMP accumulation assay described below (Section 2.6) was performed on cells with a passage number lower than 25.

\subsection{Yeast Genomic Transformation}

To develop a fluorescence-based assay to measure the downstream signaling response in yeast following ligand binding, monomeric Cherry fluorescent protein (mCherry) [69] was introduced into the FUS1 locus under control of the FUS1 promoter. To this end, overlapping fragments were first assembled in yeast using a homologous recombination as described below. The fragment consisted of the mCherry fluorescent protein and hygromycin resistance gene $h p h M x 6$ or kanamycin resistance gene KanR2 with the translation elongation factor 1 promoter and terminator (pTEF and TEFt). The fragment was flanked with approximately 300 base pairs of the Fus1 promoter and Fus1 terminator to aid in genomic recombination. The Fus1 promoter and Fus1 terminator sequences were amplified from BY4741 using colony PCR. The mCherry protein and pTEF-hphMx6-TEFt fragments were amplified from the pBS35 plasmid, while the pTEF-KanR2-TEFt fragment was amplified from the pBS7 plasmid (Figure 1B). Both pBS7 and pBS35 were obtained from the Yeast Resource Center at the University of Washington. The fragments were assembled in BY4741 using a homologous recombination using 
pRS316 as a template. Fragment assembly was verified using Sanger sequencing (Operon, Louisville, KY, USA). The resulting fragment was then amplified using PCR and transformed into yeast using the protocol from Gietz and Woods [70]. Colony PCR was used to confirm successful genomic integration. Partial sequencing confirmation of final clones was obtained for some of the transformants.

\subsection{Subcloning and Plasmid Construction}

A set of yeast expression plasmids (Table 3) containing a GPCR and C-terminal protein tags, necessary for adenosine receptor detection and quantification, was constructed using a homologous recombination in BY4741 as described previously [44]. The plasmid contains a galactose (pGAL p $\left._{10}\right)$ promoter, a pre-pro leader sequence (PP) [71] for targeting to the secretory pathway and the CYC1 terminator $\left(\mathrm{CYC1}_{\mathrm{t}}\right)$ [44]. For fluorescence microscopy, the GPCRs were C-terminally tagged for easier detection of protein expression with monomeric Citrine fluorescent protein (mCitrine) $[44,57,58,72]$. Sequencing was used to confirm the correct gene sequence for the constructs (Operon, Louisville, KY, USA).

Table 3. List of plasmids used for receptor expression in yeast and mammalian cells. Yeast expression plasmids contain an $\mathrm{N}$-terminal leader sequence (PP) to improve receptor expression and trafficking to the plasma membrane [71].

\begin{tabular}{|c|c|}
\hline Name & Plasmid \\
\hline ARJ001 & pRS316 pGal $_{1-10}$ PP A $A_{1}$ R mCit cyct \\
\hline ARJ002 & pRS316 pGal $_{1-10} \mathrm{PP} \mathrm{A}_{1} / \mathrm{A}_{2 \mathrm{~A}} \mathrm{R}$ mCit cyct \\
\hline ARJ051 & pRS316 $\mathrm{pGal}_{1-10} \mathrm{PP} \mathrm{A}_{1} / \mathrm{A}_{2 \mathrm{~A}} \Delta 316 \mathrm{R}$ mCit cyc $\mathrm{t}$ \\
\hline ARJ030 & pRS316 pGal $_{1-10} \mathrm{PP} \mathrm{A}_{2 \mathrm{~A}} \mathrm{R}$ mCit cyct \\
\hline ARJ057 & pRS316 Gal $_{1-10}$ PP A $A_{2 A} \Delta 316 R$ mCit cyct \\
\hline ARJ194 & $\mathrm{pCEP} 4 \mathrm{~A}_{1} \mathrm{R}$ \\
\hline ARJ195 & pCEP4 $\mathrm{A}_{1} / \mathrm{A}_{2 \mathrm{~A}} \mathrm{R}$ \\
\hline ARJ196 & $\mathrm{pCEP} 4 \mathrm{~A}_{1} / \mathrm{A}_{2 \mathrm{~A}} \Delta 316 \mathrm{R}$ \\
\hline CM001 & pCEP4 $A_{2 A} R$ \\
\hline CM002 & pCEP4 $\mathrm{A}_{2 \mathrm{~A}} \Delta 316 \mathrm{R}$ \\
\hline ARJ073 & 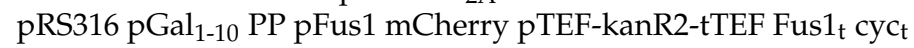 \\
\hline ARJ172 & pRS316 pGal $_{1-10}$ PP pFus1 mCherry pTEF-hphMx6-tTEF Fus1 cyct $_{t}$ \\
\hline
\end{tabular}

Mammalian expression vector pCEP4 was used for expressing receptors in transiently transfected HEK-293 cells. Untagged $A_{1} R$ and $A_{1} / A_{2 A} R$ were inserted into the pCEP4 multiple cloning site between HindIII and NotI restriction enzyme sites, whereas $A_{1} / A_{2 A} \Delta 316 R, A_{2 A} R$, and $A_{2 A} \Delta 316 R$ were inserted between KpnI and XhoI restriction enzyme sites. Transformations of E. coli were performed by the heat shock method. Sequencing was used to confirm the correct gene sequences for the plasmids (Operon, Louisville, KY, USA).

\subsection{Cyclic Adenosine Monophosphate Accumulation Assay}

Transiently transfected HEK-293 and either non-transfected cells or cells transfected with empty plasmid (control) were incubated for $30 \mathrm{~min}$ in the presence or absence of ligand (DMSO only, no ligand control) at a cell density of 1000 cells/well in a white 384-well plate (Grenier Bio-One \#784075, Monroe, NC, USA). Excess cells were pelleted and stored at $-80{ }^{\circ} \mathrm{C}$ for subsequent Western blotting. The concentration of cAMP per well was determined using the cAMP dynamic 2 kit using a BioTek Synergy H1 Plate Reader according to the manufacturer's protocol. Our previous study [73] has shown that adenosine deaminase (ADA) pre-treatment of cells did not alter the ligand binding or downstream signaling, and therefore the cells were not treated with ADA prior to ligand treatment while utilizing the CisBio HTRF kits. Experiments were performed in triplicate for three independent transfections. Data were analyzed as per manufacturer's recommendation, and mean and standard error were plotted using Prism (GraphPad, La Jolla, CA, USA). Student's $t$-test was performed using Prism to obtain the significance of the data. 


\subsection{MAPK Response Signal Determination}

Yeast cultures were grown overnight in SD-ura selection in $400 \mu \mathrm{L}$ or $1 \mathrm{~mL}$ media in 48 -well or 24-well plates (Falcon 353047 and 353078, Corning, NY, USA), respectively, at $30{ }^{\circ} \mathrm{C}$ at $275 \mathrm{rpm}$. Recombinant GPCR expression was induced by transferring $12.5 \mu \mathrm{L}$ of overnight culture into $400 \mu \mathrm{L}$ SG-ura. For some strains, $0.125 \%$ glucose was used to supplement the SG-ura media to improve cell growth of the engineered yeast strains. This level of glucose supplementation has been shown to result in minimal glucose-based suppression of the galactose promoter, as described previously [74]. Yeast cells expressing the receptor were imaged using Nikon $\mathrm{A}_{1}$ laser-scanning confocal microscope, as described in our earlier published study [44].

To determine signaling, all ligand stock solutions were prepared to the highest soluble concentration (typically around 40-100 mM) in dimethyl sulfoxide (DMSO), according to the recommendations of the manufacturer. Working concentrations of $5 \mathrm{mM}$ ligand (50X) in DMSO were used for all yeast signaling experiments. After $24 \mathrm{~h}$ of GPCR expression, twelve $\mu \mathrm{L}$ of the overnight culture was added to $380 \mu \mathrm{L}$ fresh SG-ura media per well of a 48-well plate. Eight microliters of ligand or DMSO were added to each well (final DMSO concentration at $2 \%(v / v)$ per well). Although this concentration is well above the $\mathrm{K}_{\mathrm{D}}$, a high ligand concentration has been shown previously to be needed for effective downstream signaling response in yeast [75-78]. After ligand addition, the 48-well plate was incubated at $30^{\circ} \mathrm{C}$ at $275 \mathrm{rpm}$ for $24 \mathrm{~h}$. Adenosine deaminase treatment was not required for working with the yeast-based assay, as previous studies show this treatment does not impact downstream signaling measurements $[79,80]$. Similar results were obtained from $4 \mathrm{~h}$ incubations, but the fold change difference was not as pronounced. Fluorescence intensities of $100 \mu \mathrm{L}$ of resulting liquid culture were measured in triplicate in a 96-well plate (Costar 3915, Corning, NY, USA) using a BioTek Synergy $\mathrm{H} 1$ microplate reader (Winooski, VT, USA) maintained at $30^{\circ} \mathrm{C}$. Experiments were performed for six independent transformants.

\subsection{Western Blotting}

Transiently transfected HEK-293 cells were scraped, pelleted, and resuspended in ice-cold 1X TE buffer (1\% 1M Tris-Cl pH 7.5, 0.2\% 500 mM EDTA pH 8) with protease inhibitors. Cells were sonicated with a Branson Sonifier 450 at $50 \%$ power for 30 pulses and then centrifuged at $2000 \times g$ for 5 min at $4{ }^{\circ} \mathrm{C}$ to remove cell debris and unlysed cells. The supernatant was then centrifuged at $100,000 \times g$ for $1 \mathrm{~h}$ at $4{ }^{\circ} \mathrm{C}$ to pellet cell membranes. Membranes were solubilized in 1X RIPA buffer (10 mM Tris- $\mathrm{Cl}$ ( $\left.\mathrm{pH} 8.0\right)$, $1 \mathrm{mM}$ EDTA, $0.5 \mathrm{mM}$ EGTA, 1\% Triton X-100, 0.1\% sodium deoxycholate, $0.1 \%$ SDS, $140 \mathrm{mM} \mathrm{NaCl}$ ) with protease inhibitors; if necessary, membranes were sonicated again for five pulses at $50 \%$ power to break up any visible pieces of membrane. BCA assay (Pierce; Rockford, IL, USA) was performed to determine the total protein concentration of isolated membrane, using bovine serum albumin (BSA; Thermo Fisher, Waltham, MA, USA) as a standard.

Isolated HEK cell membranes were utilized for $A_{2 A} R$ and $A_{2 A} \Delta 316 R$ protein quantification via Western immunoassay. Western blotting analysis could not be performed for untagged $A_{1} R$ and its variant due to the lack of an effective antibody against the receptor. The untagged (non-fluorescent) receptor was used for the study to not interfere with the fluorescence-based CisBio HTRF kits. A total of $10 \mu \mathrm{g}$ of total protein per sample was loaded onto a $12 \%$ Tris-Glycine gel and electrophoresed in SDS buffer at $125 \mathrm{~V}$ for $65 \mathrm{~min}$. Western immunoassay was performed using adenosine $\mathrm{A}_{2 \mathrm{~A}} \mathrm{R}$ mouse monoclonal IgG antibody (sc-32261, Santa Cruz Biotechnology, Dallas, TX, USA) at 1:5000 dilution, and Goat pAb to Mouse IgG HRP antibody at 1:5000 dilution. Membranes were imaged with the UVP BioSpectrum imaging system.

Yeast cell pellets $\left(10 \mathrm{OD}_{600}\right)$ were resuspended in $250 \mu \mathrm{L}$ lysis buffer $(10 \%$ glycerol, $50 \mathrm{mM}$ sodium phosphate, $300 \mathrm{mM}$ sodium chloride, $\mathrm{pH}$ 8) supplemented with cOmplete EDTA-free protease inhibitor cocktail (Roche, Indianapolis, IN, USA). An equal volume of $0.5 \mathrm{~mm}$ zirconia/silica beads (BioSpec, Bartlesville, OK, USA) was added to the cells and lysis was performed using a vortexer or a BeadBug homogenizer (Benchmark Scientific, Edison, NJ, USA). Cell lysates were combined with 
4X Laemmli sample loading buffer supplemented with $\beta$-mercaptoethanol (Bio-Rad, Hercules, CA, USA). One $\mathrm{OD}_{600}$ equivalent of cell lysate was loaded per well for Western blotting. Precision Plus Protein WesternC Standard (BioRad) was used as a standard to enable molecular weight estimation. Rabbit anti-GFP antibody (1:5000 dilution) and Alexa 568-donkey anti-rabbit (1:2500) was used to detect mCitrine protein-tagged receptors.

\section{Results}

\subsection{Loss of the Cytoplasmic C-Terminus Results in Loss of Downstream Signaling}

The $\mathrm{A}_{2 \mathrm{~A}} \mathrm{R}$ truncation at residue $316\left(\mathrm{~A}_{2 \mathrm{~A}} \Delta 316 \mathrm{R}\right)$ present in many crystal structures (Table 1$)$ contains helix 8 and some residues of the cytoplasmic tail, and has been reported previously to have native-like affinity for the agonist NECA and antagonist ZM 241385 in mammalian and yeast systems $[52,55,81]$. In prior studies, we showed that the full-length and truncated $\mathrm{A}_{2 \mathrm{~A}} \mathrm{R}\left(\mathrm{A}_{2 \mathrm{~A}} \Delta 316 \mathrm{R}\right)$ receptors trafficked to the yeast plasma membrane comparably and showed similar ligand-binding ability [44].

Here, HEK-293 cells were transiently transfected with pCEP4 encoding full-length or truncated receptor in order to determine the effect of the truncation on downstream signaling. $\mathrm{A}_{2 \mathrm{~A}} \mathrm{R}$ couples to $\mathrm{Gs} \alpha$, and thus agonist addition activates adenylyl cyclase, resulting in increased cAMP synthesis. As expected, cells transfected with empty plasmid showed negligible cAMP synthesis in the absence of ligand and remained unchanged following the addition of a selective $\mathrm{A}_{2 \mathrm{~A}} \mathrm{R}$ agonist, CGS21680 $(1 \mu \mathrm{M})$ (Figure 2A). The presence of full-length $\mathrm{A}_{2 \mathrm{~A}} \mathrm{R}$ led to constitutive activation in the absence of ligand as well as a significant increase in CAMP levels following agonist treatment, consistent with previous studies [73]. Surprisingly, $\mathrm{A}_{2 \mathrm{~A}} \Delta 316 \mathrm{R}$ showed no increase in cAMP levels upon agonist addition (Figure 2A). The loss of signaling for the truncated $\mathrm{A}_{2 \mathrm{~A}} \Delta 316 \mathrm{R}$ was surprising, as the agonist-bound crystal structures have been reported to be in an active state $[11,18]$, and the truncation localizes well to the cell surface (reported by our lab previously in [44]). This $\mathrm{A}_{2 \mathrm{~A}} \mathrm{R}$ truncation at residue 316 has been reported previously to have native-like binding to the agonist NECA and the antagonist ZM 241,385 by Magnani and colleagues [81] at 32 and $12 \mathrm{nM}$, respectively, compared to 20 and $1 \mathrm{nM}$ for the full-length receptor [82]. Furthermore, we find that $\mathrm{A}_{2 \mathrm{~A}} \Delta 316 \mathrm{R}$ also showed no constitutive activity, though this construct contains residues Y197 and Y288 and NPxxY in TM7 that have been reported to be important for binding $G$ protein in active structures [83]. These data show that though $\mathrm{A}_{2 \mathrm{~A}} \Delta 316 \mathrm{R}$ binds ligand, it does not activate $G s \alpha$, suggesting the C-terminus is necessary for downstream signaling of the receptor.

Western blot analysis of membrane preparations was utilized to verify that the absence of $\mathrm{A}_{2 \mathrm{~A}} \Delta 316 \mathrm{R}$ activity was not due to a lack of protein expression. Though interpretation of Western quantitation should be undertaken with caution, it is clear that there are no significant differences in the $A_{2 A} R$ and $A_{2 A} \Delta 316 R$ expression in HEK-293 cells (Figure 2B), suggesting the $>20$-fold differences seen in CAMP signaling were not the result of expression differences. Cells transfected with pCEP control vector did not show any receptor expression via Western blot analysis (Figure 2B) and previous work from our laboratory has shown that the multiple bands (particularly evident in the monomeric form) are the result of protein glycosylation that occurs in the HEK cells [84].

We further examined the expression of full-length $\mathrm{A}_{2 \mathrm{~A}} \mathrm{R}$ and $\mathrm{A}_{2 \mathrm{~A}} \Delta 316 \mathrm{R}$ with $\mathrm{C}$-terminal tagged $\mathrm{mCitrine}$ fluorescent protein fusions in yeast. Expression was confirmed using Western blot analysis (Figure 3A). Previous studies from our laboratory have shown that the C-terminal fluorescent protein fusion does not impact trafficking or downstream activation of $A_{2 A} R$ [55,85-87], and we previously reported that full-length and truncated $A_{2 A} R\left(A_{2 A} \Delta 316 R\right)$ receptor trafficked to the yeast plasma membrane comparably and showed similar ligand binding ability [44]. Confocal microscopy shows the localization of both full-length and truncated $\mathrm{A}_{2 \mathrm{~A}} \mathrm{R}$ primarily at the plasma membrane (Figure $3 \mathrm{~B}$ ). 


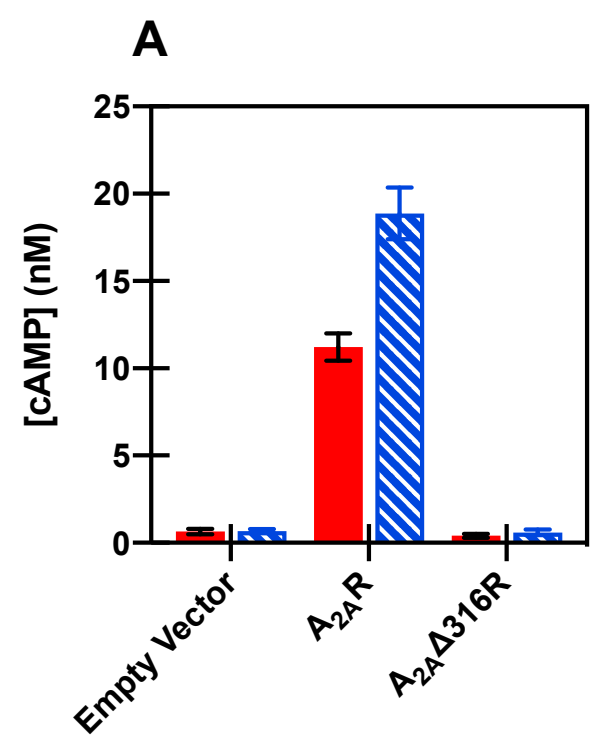

B

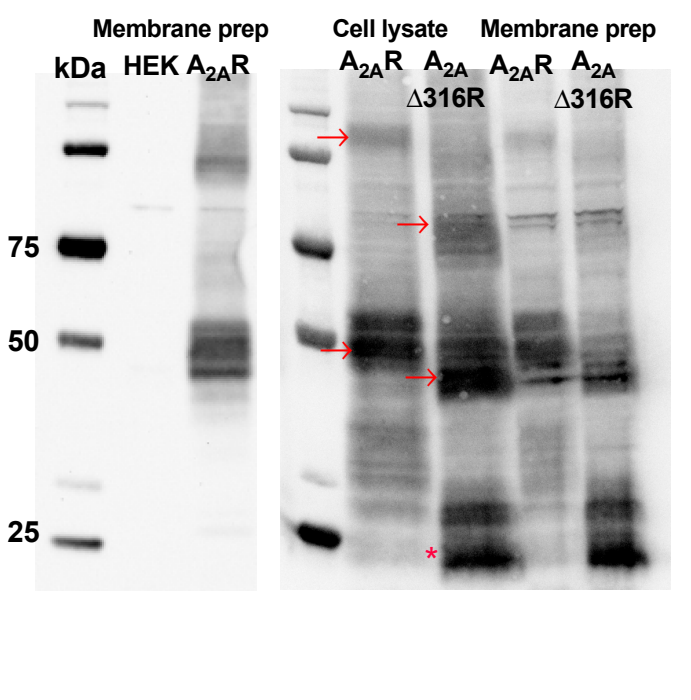

Figure 2. Transiently transfected HEK-293 cells were used to determine downstream signaling for chimeras. (A) Agonist-mediated cAMP accumulation for transiently transfected cells with $\mathrm{A}_{2 \mathrm{~A}} \mathrm{R}$ and $A_{2 A} \Delta 316 R$ (DMSO only shown in red filled bars, $1 \mu$ M CGS21680 agonist in blue hatched bars). Data represent mean \pm S.E.M. for three independent transfections performed in triplicate $\left({ }^{*} p<0.001\right.$, Student's t-test). (B) Representative Western blot analysis of $\mathrm{A}_{2 \mathrm{~A}} \mathrm{R}$ and its truncation from transiently transfected in HEK-293, as obtained from equal protein loadings of total cell lysate or membrane fractions. HEK sample shows HEK-293 cells transfected with pCEP only compared to pCEP-A $\mathrm{A}_{\mathrm{A}} \mathrm{R}$. Dimer and full-length monomeric receptor are indicated by arrows in cell lysates, and multiple forms visible-particular in the monomeric form at $\sim 50 \mathrm{kDa}$ - can be attributed to variable glycosylation. Samples of $\mathrm{A}_{2 \mathrm{~A}} \Delta 316 \mathrm{R}$ shows a smaller band visible at $\sim 30 \mathrm{kDa}$ that is likely a proteolytic product, indicated by an asterisk. Expected molecular weights for $A_{2 A} R$ is $44.7 \mathrm{kDa}$ and $\mathrm{A}_{2 \mathrm{~A}} \Delta 316 \mathrm{R}$ is $35.1 \mathrm{kDa}$, and molecular weights were determined using Precision Plus Protein Western $C$ standards.

As described in the Experimental Section, engineered yeast strains with modification to the native MAPK-based signaling pathway $[66,67]$ were further modified to replace the original Fus1 modification that relied on growth-dependent signaling (via His3 expression) in the Broach lab strain [66] or $\beta$-galactosidase reporter activity in the GSK strains [67] with an easily detectable fluorescence signal from monomeric Cherry (mCherry) fluorescent protein (Figure 1 and Table 2). Because the yeast $G$ protein-coupled signaling pathway contains homologues to proteins in the human signaling pathway, engineered yeast have been used to successfully recapitulate native ligand-binding preferences and $\mathrm{G}$ protein-coupling for human GPCRs $[66,67,79,80]$. In these engineered yeast strains, mCherry is produced in the cells upon ligand-mediated downstream signal activation via human GPCR-G $\alpha$ protein coupling (Figure 1A). The fold change in mCherry fluorescence in these strains can be easily compared by the addition of agonist relative to a control. As in HEK cells, upon agonist addition, there was no downstream signaling observed in the truncated $\mathrm{A}_{2 \mathrm{~A}} \Delta 316 \mathrm{R}$ as compared to the full-length receptor in the stimulatory yeast strain (Figure $3 C$ ). This observation is important as it allows us to use the yeast system to screen and validate receptor variant activity. 

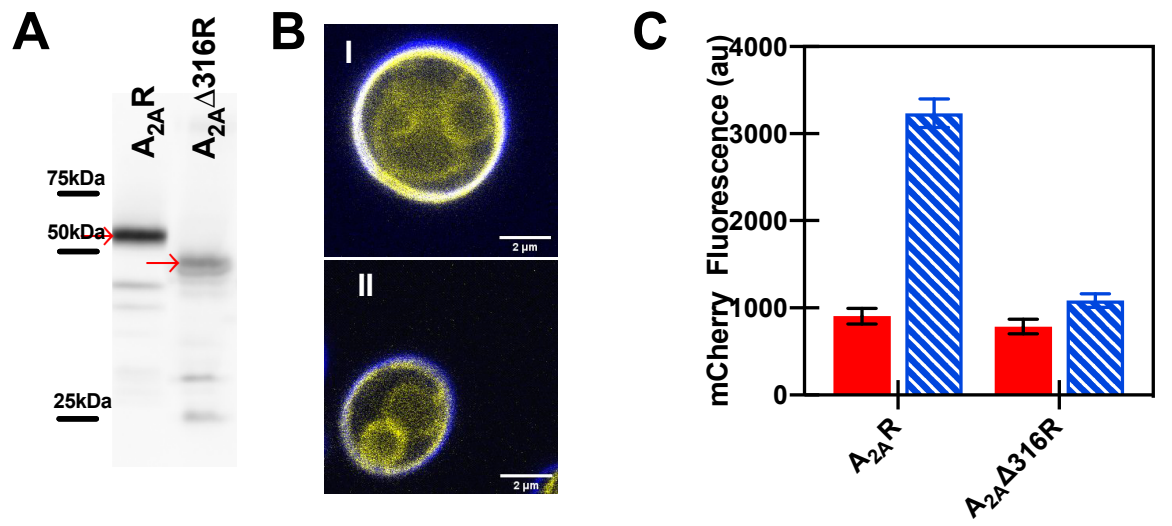

Figure 3. Truncation of the $C$-terminus for $A_{2 A} R\left(A_{2 A} \Delta 316 R\right)$ resulted in a loss of the signaling response in yeast strains. (A) Full-length expression of mCitrine tagged wild-type and truncated $\mathrm{A}_{2 \mathrm{~A}} \mathrm{R}$ was observed using Western blot analysis with an anti-GFP antibody. Full-length receptor is indicated by an arrow. Molecular weights were estimated using Precision Plus Protein Western $C$ standards. The expected molecular weight of each receptor is as follows: $A_{2 A} R, 71.6 \mathrm{kDa}$; and $A_{2 A} \Delta 316 \mathrm{R}, 66.1 \mathrm{kDa}$. Note that the mobilities are slightly faster than that expected by calculated molecular weight; membrane proteins have been found to run faster than expected, possibly due to their hydrophobicity or incomplete denaturation, due to the absence of sample heating [88]. (B) Representative confocal images of yeast cells expressing (i) $A_{2 A} R$ and (ii) $A_{2 A} \Delta 316 R$ show plasma membrane localization of the receptor. Scale bar $=2 \mu \mathrm{m}$. Images performed as described in Experimental Section. (C) MAP kinase response signaling of the full length $A_{2 A} R$ and truncated $\left(A_{2 A} \Delta 316 R\right)$ receptor in Gpa1p-G $\alpha$ s engineered strain. NECA $(100 \mu \mathrm{M})$ shown as blue hatched bars and DMSO control as red filled bars. Data represents the mean $\pm 95 \%$ C.I. for experiments performed in duplicate for three independent transformants.

\subsection{The C-Terminus Does Not Play a Role in the Specificity of G $\alpha$ Coupling}

In order to understand how the $\mathrm{C}$-terminus of $\mathrm{A}_{2 \mathrm{~A}} \mathrm{R}$ might be involved in the specificity of $\mathrm{G} \alpha$ coupling, we utilized an adenosine $\mathrm{A}_{1} / \mathrm{A}_{2 \mathrm{~A}}$ receptor chimera, where the construct contains all seven transmembrane domains of $A_{1} R$ (residues 1-290) and the C-terminus of the $A_{2 A} R$ (residues 291-412) created using homologous recombination [44]. In addition, a truncated chimera $\left(\mathrm{A}_{1} / \mathrm{A}_{2 \mathrm{~A}} \Delta 316 \mathrm{R}\right)$ consisting of the transmembrane domains of $A_{1} R$ and the C-terminus of $A_{2 A} R$ truncated at the 316th residue was constructed, consistent with the truncated $A_{2 A} \Delta 316 R$ utilized in crystallography. This truncated chimera contains the helix 8 residues of $A_{2 A} R$. In our previous study, trafficking of the $A_{1} R / A_{2 A} R$ chimera was improved relative to wild-type $A_{1} R$, with resulting improvements in radioligand binding activity to the $A_{1}$-selective ligand $\left[{ }^{3} \mathrm{H}\right]-\mathrm{DPCPX}$, as measured in whole cells [44]. The $K_{D}$ for DPCPX determined for $A_{1} / A_{2 A} R$ and $A_{1} / A_{2 A} \Delta 316 R$ were 4.8 and $7.3 \mathrm{nM}$, respectively [44], which are consistent with the reported values for $A_{1} R$ with DPCPX (0.18-6.1 nM) [89-92].

To test the role of the $\mathrm{A}_{2 \mathrm{~A}} \mathrm{R} \mathrm{C}$-terminus in $\mathrm{A}_{1} \mathrm{R}$ signaling in mammalian cells, cAMP was measured in transiently transfected HEK-293 cells. $A_{1} R$ couples to $\mathrm{G} \alpha \mathrm{i} / \mathrm{o}$, which inhibits activation of adenylyl cyclase, so in the absence of ligand there should be minimal changes to cAMP levels, consistent with our results (Figure 4). Forskolin directly activates adenylyl cyclase, which leads to stimulation of the production of cAMP even in cells not expressing $A_{1} R$, so treatment with $10 \mu \mathrm{M}$ forskolin was used to elevate the basal level of cAMP. Cells expressing $A_{1} R$ showed a reduction in cAMP following treatment with an $\mathrm{A}_{1} \mathrm{R}$-selective agonist ( $1 \mu \mathrm{M}$ CPA in the presence of $10 \mu \mathrm{M}$ forskolin).

Next, we compared cAMP activation in HEK cells for wild-type $A_{1} R$ with the $A_{1} / A_{2 A} R$ and $A_{1} / A_{2 A} \Delta 316 R$ chimeras. The addition of the $A_{2 A} R C$-terminus to $A_{1} R$ did not lead to constitutive activity of the receptor in the absence of a ligand (Figure 4, black filled bars); therefore, $10 \mu \mathrm{M}$ forskolin was used to enable a basal cAMP signal. When treated with the $\mathrm{A}_{1} \mathrm{R}$-specific agonist CPA $(1 \mu \mathrm{M}$, in the presence of $10 \mu \mathrm{M}$ forskolin), cells transfected with either $A_{1} / A_{2 A} R$ or $A_{1} / A_{2 A} \Delta 316 R$ showed a moderate reduction in cAMP signaling (72 $\pm 10 \%$ and $67 \pm 10 \%$, respectively), consistent with the 
wild-type $A_{1} R(62 \pm 3 \%)$, verifying that $A_{1} / A_{2 A} R$ and $A_{1} / A_{2 A} \Delta 316 R$ chimeras couple to G $\alpha i$ (Figure 4, red filled bars). Note that the data were normalized to cAMP levels for forskolin treated cells for each variant.

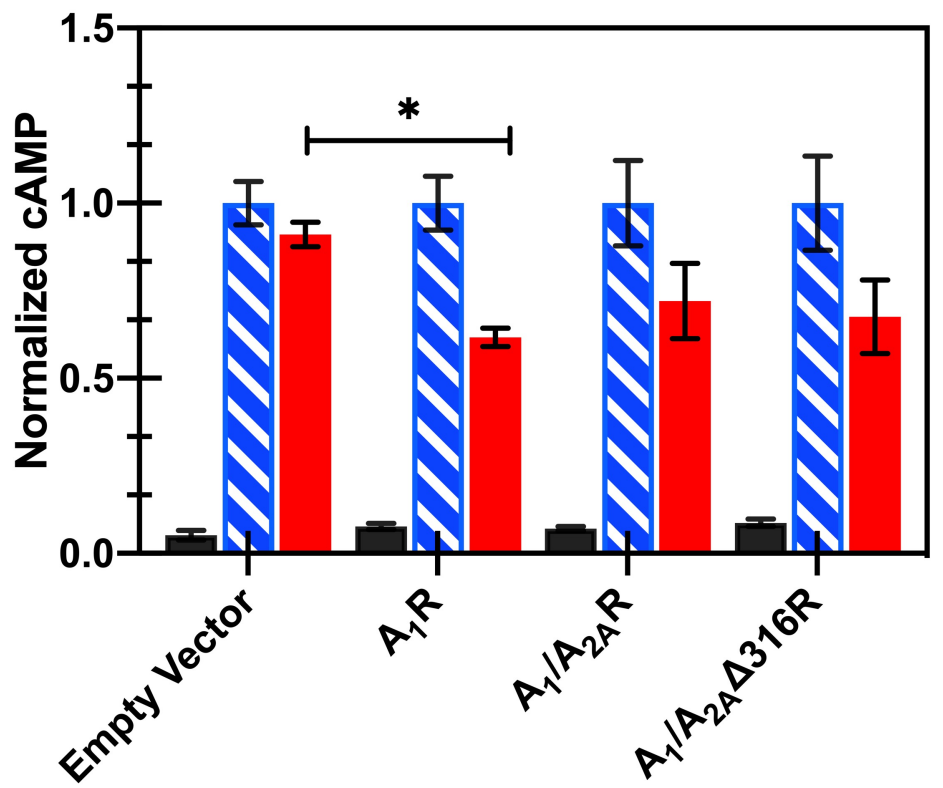

Figure 4. Expression of $A_{1} R$ or $A_{1} / A_{2 A} R$ chimeras in HEK-293 cells results in inhibition of cAMP production after forskolin stimulation. Inhibition of $c A M P$ production with $A_{1} R$ and compared to $p C E P$ (empty) vector controls and $A_{1} / A_{2 A} R$ and $A_{1} / A_{2 A} \Delta 316 R$ chimeras (no ligand in black filled bars, $10 \mu \mathrm{M}$ forskolin in blue hatched bars, $10 \mu \mathrm{M}$ forskolin and $1 \mu \mathrm{M}$ CPA in red filled bars). Data represent the mean \pm S.E.M. for three independent transfections performed in triplicate ( ${ }^{*} p<0.001$, Student's $t$-test).

To recreate a cellular library of human GPCR downstream signaling, twelve strains containing different yeast-human $\mathrm{G} \alpha$ chimeras that reproduce downstream signaling responses of human $\mathrm{G} \alpha$ proteins [67] were modified, as described in Section 3.1 above, to enable MAPK-activated increases

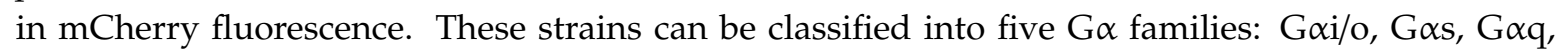
$\mathrm{G} \alpha 12$ and native $\mathrm{G} \alpha$. First, to ensure full-length human $\mathrm{A}_{1} \mathrm{R}$ showed mammalian coupling behavior in yeast, we mapped the interaction between the $A_{1}$ adenosine receptors and the appropriate $G \alpha$ in the engineered $\mathrm{G} \alpha$ chimera strains, using the non-selective high-affinity adenosine receptor family agonist, NECA $(100 \mu \mathrm{M}$, Figure $5 \mathrm{~A}) . \mathrm{A}_{1} \mathrm{R}$ showed a signaling response upon agonist addition with the inhibitory $\mathrm{G} \alpha$ family (G $\alpha \mathrm{i} 1, \mathrm{G} \alpha \mathrm{i} 3, \mathrm{G} \alpha \mathrm{o}$ and $\mathrm{G} \alpha \mathrm{z}$ ) and the promiscuous G $\alpha 16$ (Figure 5A), as expected for this receptor based on the mammalian preferences for inhibitory G $\alpha$ s. The highest fold change between cells treated with NECA as compared to DMSO-treated cells was observed for the yeast strain expressing the Gpa1-G $\alpha$ o chimera. Note that ligand levels used for these studies were well above expected $\mathrm{K}_{\mathrm{D}}$ values; however, the use of high ligand concentration is consistent with earlier studies $[67,79,80,93]$, and perhaps reflects the reduced ability of hydrophobic ligand to penetrate the chitosan-rich yeast cell wall and then reach the plasma membrane, resulting in an apparent reduced effective ligand concentration at the membrane.

To ensure that our results were not strain-dependent, we compared the signaling response obtained

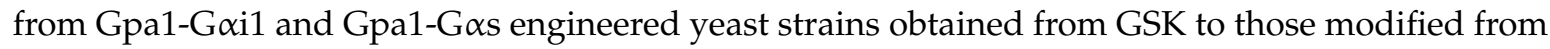
those of the Broach laboratory. Consistent with those from the GSK laboratory strains (Figure 5A), $A_{1}$ receptors maintained their native $G \alpha$ coupling-specificity (Figure 5B). Although both strains are derived from W303 parental yeast cells, interestingly, the Broach laboratory strains showed a higher fold change in mCherry fluorescence, as well as a reduced constitutive activity. Because of the higher fold change in fluorescence compared to the GSK strains, the Broach strains were utilized for subsequent studies. 
Expression of the chimeras was observed using Western blot analysis (Figure 6A) and confocal microscopy shows the localization of both full-length and truncated $A_{1} / A_{2 A} R$ chimeras to the plasma membrane (Figure $6 \mathrm{Bii}$ and iii) as compared to wild-type $\mathrm{A}_{1}$ receptor (Figure $6 \mathrm{Bi}$ ). The downstream signaling response was evaluated in the inhibitory (Figure 6C) and stimulatory (Figure 6D) yeast reporter strains, and both chimeras showed coupling with the inhibitory yeast strain, similar to wild-type $A_{1} R$, though the $A_{1} / A_{2 A} \Delta 316 R$ chimera showed reduced MAPK signaling via lower mCherry levels than the full-length $A_{1} / A_{2 A} R$ chimera. No signaling response was obtained in the stimulatory yeast strains for the $A_{1} R$ variants (Figure $6 D$ ). This observation suggests that the presence of the $A_{2 A} R C$-terminus does not affect the interaction of the chimeric $A_{1} / A_{2 A}$ receptors with the native-like inhibitory $G \alpha$ and that it does not become non-selective, i.e., by binding to all $\mathrm{G} \alpha$ proteins. This observation is consistent with previously published work with canine $A_{1} R$ and $A_{2 A} R$, where an $A_{1} R$ chimera showed native coupling with $\mathrm{G} \alpha \mathrm{i} / \mathrm{o}$ [60]. We also determined the dose-dependent mCherry fluorescence response for $A_{1} R$ and the $A_{1} / A_{2 A} R$ chimera and found that they were statistically equivalent when the non-specific agonist, NECA, was added (Figure 6E).

A

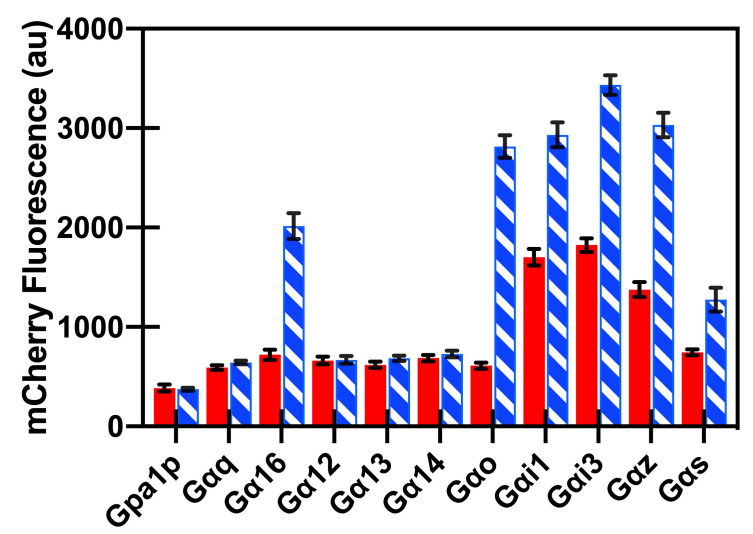

B

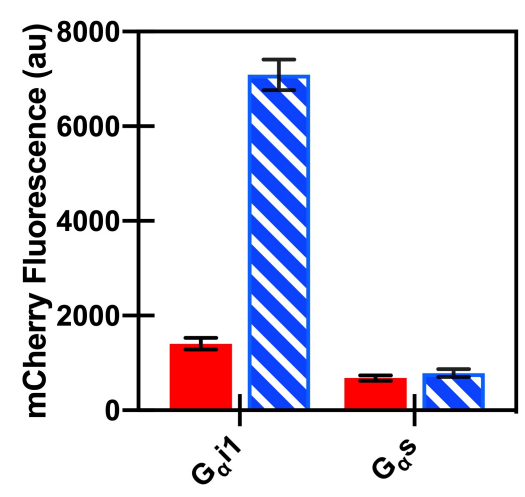

Figure 5. Downstream signaling in engineered yeast cells enables determination of G $\alpha$ coupling preferences. Agonist (100 $\mu \mathrm{M}$ NECA, blue hatched bars) mediated downstream signaling responses as compared to control (DMSO, red filled bars) for $\mathrm{A}_{1} \mathrm{R}$ were measured in yeast expressing Gpa1p-human $\mathrm{G} \alpha$ chimeras ( mean \pm S.D., for three independent experiments) for either modified GSK strains (A) or Broach laboratory strains (B). 

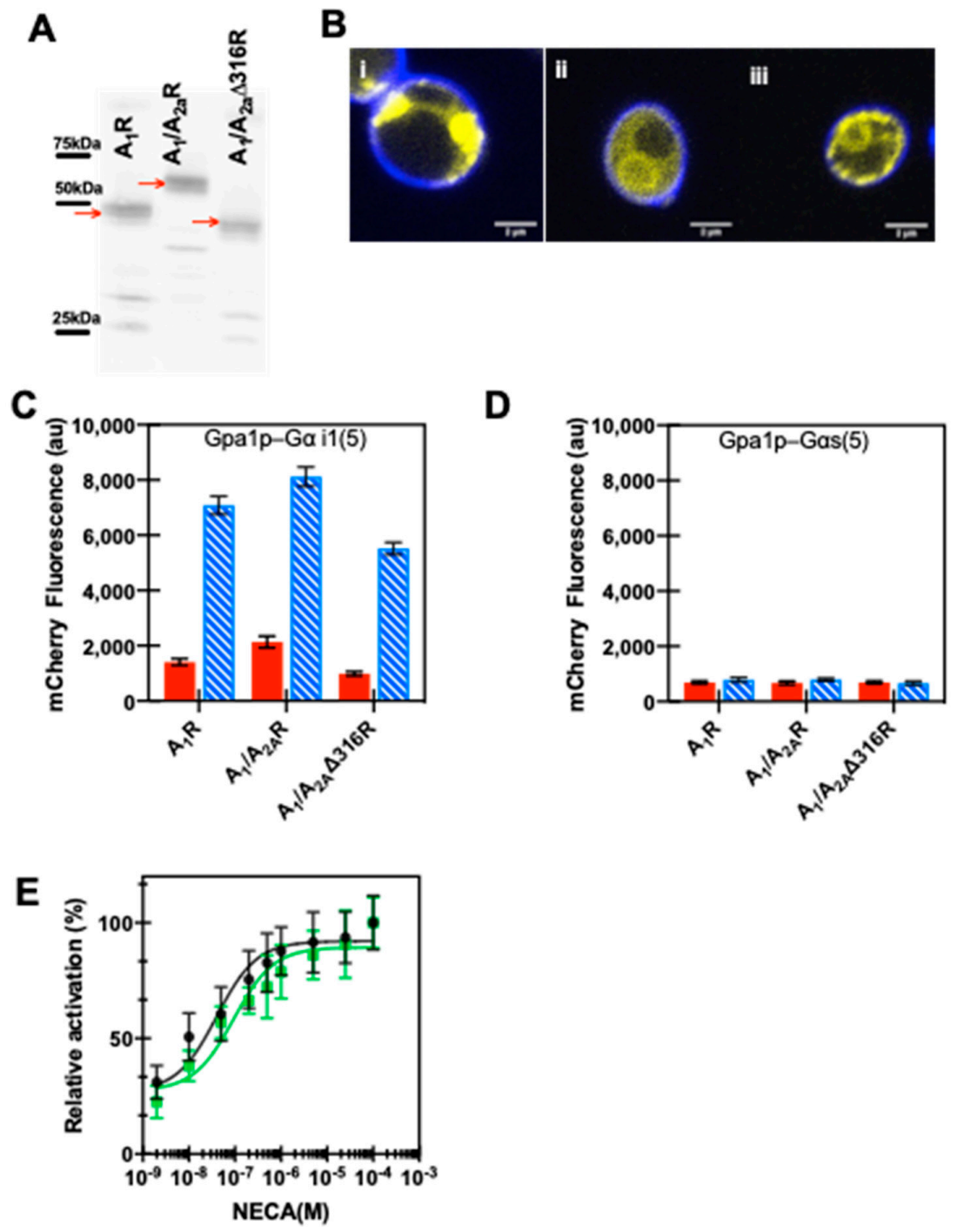

Figure 6. Expression and downstream MAPK signaling response in yeast for $A_{1} / A_{2 A} R$ and $A_{1} / A_{2 A} \Delta 316 R$ chimeras show native $A_{1} R$-like behavior. (A) Western blot images showing expression of mCitrine tagged receptors for full-length and truncated chimeric receptors. Precision Plus Protein Western $C$ standards were used to determine molecular weight as indicated. The expected molecular weight of each receptor with mCitrine is as follows: $A_{1} R, 63.4 \mathrm{kDa} ; \mathrm{A}_{1} / \mathrm{A}_{2 \mathrm{~A}} \mathrm{R}-71.5 \mathrm{kDa}$ and $\mathrm{A}_{1} / \mathrm{A}_{2 \mathrm{~A}} \Delta 316 \mathrm{R}-62.3 \mathrm{kDa}$. Note that the mobilities are slightly faster than that expected by calculated molecular weight; membrane proteins have been found to run faster than expected, possibly due to their hydrophobicity or incomplete denaturation, due to the absence of sample heating [88]. (B) Representative confocal images of yeast strains showing receptor localization of $A_{1} R(i)$, and $A_{1} / A_{2 A} R$ (ii) and $A_{1} / A_{2 A} \Delta 316 R$ (iii). Cells were stained with fluorescent brightener calcofluor white M2R (F3543; Sigma-Aldrich) that binds to chitin in the yeast cell wall prior to imaging, and this stain is shown in blue, while mCitrine fluorescence is shown in yellow. Scale bar $=2 \mu \mathrm{m}$. (C,D) Downstream signaling response of receptor variants in inhibitory Gpa1p-G $\alpha$ i1(5) (C) or stimulatory Gpa1p-G $\alpha$ s(5) strain (D). $A_{1} / A_{2 A} R$ and $A_{1} / A_{2 A} \Delta 316 R$ produce signaling response similar to $A_{1} R$ in inhibitory strain; however, none of the receptors produce a response in stimulatory strain. $100 \mu \mathrm{M} \mathrm{NECA}$ is shown as blue hatched bars and DMSO in red filled bars. (E) Dose-response curve for $A_{1} / A_{2 A} R$ chimera (green squares) is similar to the native $A_{1} R$ receptor (black circles). Data represent the mean $\pm 95 \%$ C.I. for experiments performed in duplicate for three independent transformants. 


\section{Discussion}

Since the early 1990s, the engineered yeast MAPK response pathway has been known as a useful tool to study human GPCR signaling and identify lead drug candidates by recapitulating native dose-response binding preferences $[63,66,93]$. Both $A_{1} R$ and $A_{2 A} R$ have been shown previously to interact with yeast/human chimeric $\mathrm{G} \alpha$ protein to produce downstream signaling responses in the engineered yeast $[79,80,93,94]$. Here, these yeast strains were further engineered with a fluorescence reporter and also successfully captured $A_{1} R$ and $A_{2 A} R$ downstream signaling via their corresponding native $\mathrm{G} \alpha$ proteins. Strains obtained from the Broach laboratory showed a higher fold change than those from the Dowell (GSK) laboratory under these conditions, although both strains were derived from parental W303 cells, indicating that strain differences outside of the FUS1 locus can impact the results obtained in cell-based assays.

One of the strengths of the engineered yeast system is the capability of quantifying the GPCR-G $\alpha$ interaction at a common endpoint of the signaling cascade. This allows direct comparison of the strengths of the activation for different $G \alpha$ biased ligands. One such study performed by

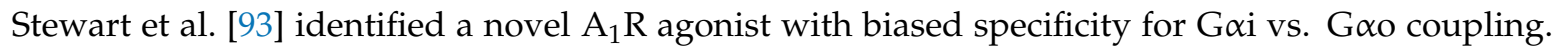
Efforts have been made to replicate this approach of utilizing the last five amino acids of the C-terminus of the $G \alpha$ protein into a mammalian system using $G \alpha$ s or $G \alpha q$ as templates [95,96]. A study by Hsu and Lou [95] in HEK-293 cells tested the interaction of $A_{1} R$ with G $\alpha$ s chimeras via a cAMP assay.

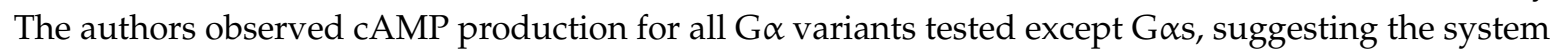
was not effective in capturing the specificity of the interaction of $A_{1} R$ with $G \alpha$ proteins. The higher than native levels of $\mathrm{G} \alpha$ protein expressed ( three-fold higher than mock transfected, native HEK) [97,98] and the presence of additional GPCRs present in the HEK cells may have contributed to signal promiscuity [99]. In our study, all the signaling components in the engineered yeast were expressed under their native promoters and, perhaps as a result, the yeast cell assay more effectively captured the specificity of GPCR-G $\alpha$ interaction.

The long C-terminus of the $\mathrm{A}_{2 \mathrm{~A}} \mathrm{R}$ (122 amino acids) is assumed to be highly flexible and disordered; thus, crystallization of adenosine receptors has all focused on using truncated receptors. Here, we found that $A_{2 A} \Delta 316 R$ resulted in no downstream cAMP signaling, and that the $A_{2 A} R$ C-terminus did not change the G-protein coupling preference from $G \alpha i$ to $G \alpha$ s for the $A_{1} / A_{2 A} R$ variants. Our results were consistent with previously published work by Tucker et al. [60] that found that a chimera of canine $A_{1} R$ with a canine $A_{2 A} R$ C-terminus showed no change in $\mathrm{G}$-protein coupling behavior. The $A_{1} / A_{2 A} R$ chimera showed a dose-dependent MAPK response similar to the wild-type human $A_{1} R$ receptor in the yeast system, suggesting there was no change in G-protein coupling behavior due to the presence of the $A_{2 A} R C$-terminus. Taken together with our previous results of exceptional yields of the chimera that binds $A_{1} R$-selective agonist [44], these data suggest that $A_{1} / A_{2 A} R$ could be an effective variant to study biophysical characteristics and function for the $\mathrm{A}_{1}$ receptor. Previously, we have reported that a similar $A_{3} / A_{2 A} R$ chimera, consisting of the $A_{3} R$ transmembrane

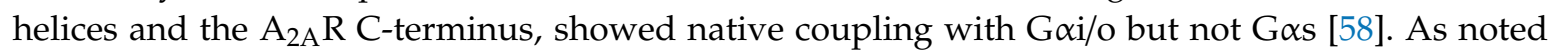
in the introduction, the C-terminus of $\mathrm{A}_{2 \mathrm{~A}} \mathrm{R}$ has some special properties, such as the absence of the canonical cysteine for palmitoylation (position 309 in $\mathrm{A}_{2 \mathrm{~A}} \mathrm{R}$ ) that may potentially add flexibility to bind interaction partners [48]. Thus, although these results are of interest for the adenosine receptors family, more experiments will need to be performed to understand the general applicability of this chimeric approach to another class A GPCR subfamily.

The $A_{2 A} R$ C-terminus is known to interact with many accessory proteins in the GPCR signaling pathways like $G$ protein receptor kinases and $\beta$-arrestins that aid in receptor signaling and desensitization [47,48,100], but has previously been thought to be dispensable for G-protein signaling [52,54]. Bennett et al. [53] showed that $\mathrm{A}_{2 \mathrm{~A}} \Delta 316 \mathrm{R}$ expressed by an inducible promoter was capable of coupling to $G \alpha$ s in a receptor expression-level dependent manner; however, their data were normalized, and total cAMP levels were not reported. We do see a small increase in ligand-dependent signaling for the $\mathrm{A}_{2 \mathrm{~A}} \Delta 316 \mathrm{R}$ truncation (Figure $2 \mathrm{~A}$ ), but the signal is over twenty-fold less than wild 
type $A_{2 A} R$, suggesting the truncation is responsible for the loss of $G$ protein signaling. Taken together, our results highlight the role of the $C$-terminus for $A_{2 A} R$ and $A_{1} R$ in $G$-protein coupling, but not in G-protein specificity.

Author Contributions: A.R.J. and A.S.R. designed the research plan; A.R.J. and C.M. performed experiments; A.R.J., C.M. and A.S.R. analyzed the data; and A.R.J. and A.S.R. wrote the manuscript. All authors have read and agreed to the published version of the manuscript.

Funding: Support for this research was obtained from the Catherine and Boh Endowment fund and NIH R01GM120351.

Acknowledgments: The authors thank James Broach for providing the CY13393 and CY13399 yeast strains and Simon Dowell (Glaxo Smith Kline, UK) for providing Gpa1-human G $\alpha$ chimera yeast strains.

Conflicts of Interest: The authors declare no conflict of interest.

\section{References}

1. Hill, S.J. G-protein-coupled receptors: Past, present and future. Br. J. Pharmacol. 2006, 147 (Suppl. S1), S27-S37. [CrossRef]

2. Elion, E.A. Pheromone response, mating and cell biology. Curr. Opin. Microbiol. 2000, 3, 573-581. [CrossRef]

3. McNeely, P.M.; Naranjo, A.N.; Robinson, A.S. Structure-function studies with G protein-coupled receptors as a paradigm for improving drug discovery and development of therapeutics. Biotechnol. J. 2012, 7, 1451-1461. [CrossRef] [PubMed]

4. Hauser, A.S.; Chavali, S.; Masuho, I.; Jahn, L.J.; Martemyanov, K.A.; Gloriam, D.E.; Babu, M.M. Pharmacogenomics of GPCR Drug Targets. Cell 2018, 172, 41-54.e19. [CrossRef] [PubMed]

5. Blocker, K.M.; Britton, Z.T.; Naranjo, A.N.; McNeely, P.M.; Young, C.L.; Robinson, A.S. Recombinant $\mathrm{G}$ protein-coupled receptor expression in Saccharomyces cerevisiae for protein characterization. Methods Enzymol. 2015, 556, 165-183. [CrossRef] [PubMed]

6. Chiu, M.L.; Tsang, C.; Grihalde, N.; MacWilliams, M.P. Over-expression, solubilization, and purification of G protein-coupled receptors for structural biology. Comb. Chem. High Throughput Screen 2008, 11, 439-462. [CrossRef]

7. Lundstrom, K.; Wagner, R.; Reinhart, C.; Desmyter, A.; Cherouati, N.; Magnin, T.; Zeder-Lutz, G.; Courtot, M.; Prual, C.; Andre, N.; et al. Structural genomics on membrane proteins: Comparison of more than 100 GPCRs in 3 expression systems. J. Struct. Funct. Genomics 2006, 7, 77-91. [CrossRef]

8. O’Malley, M.A.; Mancini, J.D.; Young, C.L.; McCusker, E.C.; Raden, D.; Robinson, A.S. Progress toward heterologous expression of active G-protein-coupled receptors in Saccharomyces cerevisiae: Linking cellular stress response with translocation and trafficking. Protein Sci. 2009, 18, 2356-2370. [CrossRef]

9. Jaakola, V.P.; Griffith, M.T.; Hanson, M.A.; Cherezov, V.; Chien, E.Y.; Lane, J.R.; Ijzerman, A.P.; Stevens, R.C. The 2.6 angstrom crystal structure of a human A2A adenosine receptor bound to an antagonist. Science 2008, 322, 1211-1217. [CrossRef]

10. Xu, F.; Wu, H.; Katritch, V.; Han, G.W.; Jacobson, K.A.; Gao, Z.G.; Cherezov, V.; Stevens, R.C. Structure of an agonist-bound human A2A adenosine receptor. Science 2011, 332, 322-327. [CrossRef]

11. Lebon, G.; Warne, T.; Edwards, P.C.; Bennett, K.; Langmead, C.J.; Leslie, A.G.; Tate, C.G. Agonist-bound adenosine A2A receptor structures reveal common features of GPCR activation. Nature 2011, 474, 521-525. [CrossRef] [PubMed]

12. Dore, A.S.; Robertson, N.; Errey, J.C.; Ng, I.; Hollenstein, K.; Tehan, B.; Hurrell, E.; Bennett, K.; Congreve, M.; Magnani, F.; et al. Structure of the adenosine A(2A) receptor in complex with ZM241385 and the xanthines XAC and caffeine. Structure 2011, 19, 1283-1293. [CrossRef] [PubMed]

13. Hino, T.; Arakawa, T.; Iwanari, H.; Yurugi-Kobayashi, T.; Ikeda-Suno, C.; Nakada-Nakura, Y.; Kusano-Arai, O.; Weyand, S.; Shimamura, T.; Nomura, N.; et al. G-protein-coupled receptor inactivation by an allosteric inverse-agonist antibody. Nature 2012, 482, 237-240. [CrossRef] [PubMed]

14. Congreve, M.; Andrews, S.P.; Dore, A.S.; Hollenstein, K.; Hurrell, E.; Langmead, C.J.; Mason, J.S.; Ng, I.W.; Tehan, B.; Zhukov, A.; et al. Discovery of 1,2,4-triazine derivatives as adenosine A(2A) antagonists using structure based drug design. J. Med. Chem. 2012, 55, 1898-1903. [CrossRef] 
15. Liu, W.; Chun, E.; Thompson, A.A.; Chubukov, P.; Xu, F.; Katritch, V.; Han, G.W.; Roth, C.B.; Heitman, L.H.; IJzerman, A.P.; et al. Structural basis for allosteric regulation of GPCRs by sodium ions. Science 2012, 337, 232-236. [CrossRef]

16. Lebon, G.; Edwards, P.C.; Leslie, A.G.; Tate, C.G. Molecular Determinants of CGS21680 Binding to the Human Adenosine A2A Receptor. Mol. Pharmacol. 2015, 87, 907-915. [CrossRef]

17. Segala, E.; Guo, D.; Cheng, R.K.; Bortolato, A.; Deflorian, F.; Dore, A.S.; Errey, J.C.; Heitman, L.H.; AP, I.J.; Marshall, F.H.; et al. Controlling the Dissociation of Ligands from the Adenosine A2A Receptor through Modulation of Salt Bridge Strength. J. Med. Chem. 2016, 59, 6470-6479. [CrossRef]

18. Carpenter, B.; Nehme, R.; Warne, T.; Leslie, A.G.; Tate, C.G. Structure of the adenosine A(2A) receptor bound to an engineered $G$ protein. Nature 2016, 536, 104-107. [CrossRef]

19. Batyuk, A.; Galli, L.; Ishchenko, A.; Han, G.W.; Gati, C.; Popov, P.A.; Lee, M.Y.; Stauch, B.; White, T.A.; Barty, A.; et al. Native phasing of X-ray free-electron laser data for a $\mathrm{G}$ protein-coupled receptor. Sci. Adv. 2016, 2, e1600292. [CrossRef]

20. Sun, B.; Bachhawat, P.; Chu, M.L.; Wood, M.; Ceska, T.; Sands, Z.A.; Mercier, J.; Lebon, F.; Kobilka, T.S.; Kobilka, B.K. Crystal structure of the adenosine A2A receptor bound to an antagonist reveals a potential allosteric pocket. Proc. Natl. Acad. Sci. USA 2017, 114, 2066-2071. [CrossRef]

21. Martin-Garcia, J.M.; Conrad, C.E.; Nelson, G.; Stander, N.; Zatsepin, N.A.; Zook, J.; Zhu, L.; Geiger, J.; Chun, E.; Kissick, D.; et al. Serial millisecond crystallography of membrane and soluble protein microcrystals using synchrotron radiation. IUCrJ 2017, 4, 439-454. [CrossRef] [PubMed]

22. Melnikov, I.; Polovinkin, V.; Kovalev, K.; Gushchin, I.; Shevtsov, M.; Shevchenko, V.; Mishin, A.; Alekseev, A.; Rodriguez-Valera, F.; Borshchevskiy, V.; et al. Fast iodide-SAD phasing for high-throughput membrane protein structure determination. Sci. Adv. 2017, 3, e1602952. [CrossRef] [PubMed]

23. Cheng, R.K.Y.; Segala, E.; Robertson, N.; Deflorian, F.; Dore, A.S.; Errey, J.C.; Fiez-Vandal, C.; Marshall, F.H.; Cooke, R.M. Structures of Human $\mathrm{A}_{1}$ and $\mathrm{A}_{2} \mathrm{~A}$ Adenosine Receptors with Xanthines Reveal Determinants of Selectivity. Structure 2017, 25, 1275-1285.e1274. [CrossRef] [PubMed]

24. Weinert, T.; Olieric, N.; Cheng, R.; Brunle, S.; James, D.; Ozerov, D.; Gashi, D.; Vera, L.; Marsh, M.; Jaeger, K.; et al. Serial millisecond crystallography for routine room-temperature structure determination at synchrotrons. Nat. Commun. 2017, 8, 542. [CrossRef]

25. Broecker, J.; Morizumi, T.; Ou, W.L.; Klingel, V.; Kuo, A.; Kissick, D.J.; Ishchenko, A.; Lee, M.Y.; Xu, S.; Makarov, O.; et al. High-throughput in situ X-ray screening of and data collection from protein crystals at room temperature and under cryogenic conditions. Nat. Protoc. 2018, 13, 260-292. [CrossRef]

26. Eddy, M.T.; Lee, M.Y.; Gao, Z.G.; White, K.L.; Didenko, T.; Horst, R.; Audet, M.; Stanczak, P.; McClary, K.M.; Han, G.W.; et al. Allosteric Coupling of Drug Binding and Intracellular Signaling in the A2A Adenosine Receptor. Cell 2018, 172, 68-80.e12. [CrossRef]

27. Rucktooa, P.; Cheng, R.K.Y.; Segala, E.; Geng, T.; Errey, J.C.; Brown, G.A.; Cooke, R.M.; Marshall, F.H.; Dore, A.S. Towards high throughput GPCR crystallography: In Meso soaking of Adenosine A2A Receptor crystals. Sci. Rep. 2018, 8, 41. [CrossRef]

28. White, K.L.; Eddy, M.T.; Gao, Z.G.; Han, G.W.; Lian, T.; Deary, A.; Patel, N.; Jacobson, K.A.; Katritch, V.; Stevens, R.C. Structural Connection between Activation Microswitch and Allosteric Sodium Site in GPCR Signaling. Structure 2018, 26, 259-269.e255. [CrossRef]

29. Garcia-Nafria, J.; Lee, Y.; Bai, X.; Carpenter, B.; Tate, C.G. Cryo-EM structure of the adenosine A2A receptor coupled to an engineered heterotrimeric G protein. Elife 2018, 7. [CrossRef]

30. Martin-Garcia, J.M.; Zhu, L.; Mendez, D.; Lee, M.Y.; Chun, E.; Li, C.; Hu, H.; Subramanian, G.; Kissick, D.; Ogata, C.; et al. High-viscosity injector-based pink-beam serial crystallography of microcrystals at a synchrotron radiation source. IUCrJ 2019, 6, 412-425. [CrossRef]

31. Shimazu, Y.; Tono, K.; Tanaka, T.; Yamanaka, Y.; Nakane, T.; Mori, C.; Terakado Kimura, K.; Fujiwara, T.; Sugahara, M.; Tanaka, R.; et al. High-viscosity sample-injection device for serial femtosecond crystallography at atmospheric pressure. J. Appl. Crystallogr. 2019, 52, 1280-1288. [CrossRef] [PubMed]

32. Ishchenko, A.; Stauch, B.; Han, G.W.; Batyuk, A.; Shiriaeva, A.; Li, C.; Zatsepin, N.; Weierstall, U.; Liu, W.; Nango, E.; et al. Toward G protein-coupled receptor structure-based drug design using X-ray lasers. IUCrJ 2019, 6, 1106-1119. [CrossRef] [PubMed] 
33. Jespers, W.; Verdon, G.; Azuaje, J.; Majellaro, M.; Keranen, H.; Garcia-Mera, X.; Congreve, M.; Deflorian, F.; de Graaf, C.; Zhukov, A.; et al. X-ray Crystallography and Free Energy Calculations Reveal the Binding Mechanism of A2A Adenosine Receptor Antagonists. Angew. Chem. Int. Ed. Engl. 2020. [CrossRef] [PubMed]

34. Lee, M.Y.; Geiger, J.; Ishchenko, A.; Han, G.W.; Barty, A.; White, T.A.; Gati, C.; Batyuk, A.; Hunter, M.S.; Aquila, A.; et al. Harnessing the power of an X-ray laser for serial crystallography of membrane proteins crystallized in lipidic cubic phase. IUCrJ 2020, 7, 976-984. [CrossRef] [PubMed]

35. Borodovsky, A.; Barbon, C.M.; Wang, Y.; Ye, M.; Prickett, L.; Chandra, D.; Shaw, J.; Deng, N.; Sachsenmeier, K.; Clarke, J.D.; et al. Small molecule AZD4635 inhibitor of $\mathrm{A}_{2 \mathrm{~A}} \mathrm{R}$ signaling rescues immune cell function including CD103(+) dendritic cells enhancing anti-tumor immunity. J. Immunother. Cancer 2020, 8. [CrossRef] [PubMed]

36. Ihara, K.; Hato, M.; Nakane, T.; Yamashita, K.; Kimura-Someya, T.; Hosaka, T.; Ishizuka-Katsura, Y.; Tanaka, R.; Tanaka, T.; Sugahara, M.; et al. Isoprenoid-chained lipid EROCOC17+4: A new matrix for membrane protein crystallization and a crystal delivery medium in serial femtosecond crystallography. Sci. Rep. 2020, 10, 19305. [CrossRef] [PubMed]

37. Glukhova, A.; Thal, D.M.; Nguyen, A.T.; Vecchio, E.A.; Jorg, M.; Scammells, P.J.; May, L.T.; Sexton, P.M.; Christopoulos, A. Structure of the Adenosine $A_{1}$ Receptor Reveals the Basis for Subtype Selectivity. Cell 2017, 168, 867-877.e813. [CrossRef]

38. Draper-Joyce, C.J.; Khoshouei, M.; Thal, D.M.; Liang, Y.L.; Nguyen, A.T.N.; Furness, S.G.B.; Venugopal, H.; Baltos, J.A.; Plitzko, J.M.; Danev, R.; et al. Structure of the adenosine-bound human adenosine $\mathrm{A}_{1}$ receptor-Gi complex. Nature 2018, 558, 559-563. [CrossRef]

39. Fredholm, B.B.; AP, I.J.; Jacobson, K.A.; Klotz, K.N.; Linden, J. International Union of Pharmacology. XXV. Nomenclature and classification of adenosine receptors. Pharmacol. Rev. 2001, 53, 527-552.

40. Fredholm, B.B.; AP, I.J.; Jacobson, K.A.; Linden, J.; Muller, C.E. International Union of Basic and Clinical Pharmacology. LXXXI. Nomenclature and classification of adenosine receptors-An update. Pharmacol. Rev. 2011, 63, 1-34. [CrossRef]

41. McIntosh, V.J.; Lasley, R.D. Adenosine receptor-mediated cardioprotection: Are all 4 subtypes required or redundant? J. Cardiovasc. Pharmacol. Ther. 2012, 17, 21-33. [CrossRef] [PubMed]

42. Fredholm, B.B.; Chen, J.F.; Cunha, R.A.; Svenningsson, P.; Vaugeois, J.M. Adenosine and brain function. Int. Rev. Neurobiol. 2005, 63, 191-270. [CrossRef] [PubMed]

43. Chen, J.F.; Eltzschig, H.K.; Fredholm, B.B. Adenosine receptors as drug targets-What are the challenges? Nat. Rev. Drug Discov. 2013, 12, 265-286. [CrossRef] [PubMed]

44. Jain, A.R.; Stradley, S.H.; Robinson, A.S. The A2aR C-terminus provides improved total and active expression yields for adenosine receptor chimeras. AIChE J. 2018, 64, 4297-4307. [CrossRef]

45. Britton, Z.T. Novel Approaches to the Expression and Purification of G Protein-Coupled Receptors; University of Delaware: Newark, Delaware, 2012; p. 3526401.

46. Moriyama, K.; Sitkovsky, M.V. Adenosine A2A receptor is involved in cell surface expression of A2B receptor. J. Biol. Chem. 2010, 285, 39271-39288. [CrossRef]

47. Gsandtner, I.; Freissmuth, M. A tail of two signals: The $C$ terminus of the $A(2 \mathrm{~A})$-adenosine receptor recruits alternative signaling pathways. Mol. Pharmacol. 2006, 70, 447-449. [CrossRef]

48. Zezula, J.; Freissmuth, M. The A(2A)-adenosine receptor: A GPCR with unique features? Br. J. Pharmacol. 2008, 153 (Suppl. S1), S184-S190. [CrossRef]

49. Navarro, G.; Cordomi, A.; Brugarolas, M.; Moreno, E.; Aguinaga, D.; Perez-Benito, L.; Ferre, S.; Cortes, A.; Casado, V.; Mallol, J.; et al. Cross-communication between Gi and Gs in a G-protein-coupled receptor heterotetramer guided by a receptor C-terminal domain. BMC Biol. 2018, 16, 24. [CrossRef]

50. Weiss, H.M.; Grisshammer, R. Purification and characterization of the human adenosine A(2a) receptor functionally expressed in Escherichia coli. Eur. J. Biochem. 2002, 269, 82-92. [CrossRef]

51. Singh, S.; Hedley, D.; Kara, E.; Gras, A.; Iwata, S.; Ruprecht, J.; Strange, P.G.; Byrne, B. A purified C-terminally truncated human adenosine $\mathrm{A}(2 \mathrm{~A})$ receptor construct is functionally stable and degradation resistant. Protein Expr. Purif 2010, 74, 80-87. [CrossRef] [PubMed]

52. Palmer, T.M.; Stiles, G.L. Identification of an A2a Adenosine Receptor Domain Specifically Responsible for Mediating Short-Term Desensitization. Biochemistry 1997, 36, 832-838. [CrossRef] [PubMed] 
53. Bennett, K.A.; Tehan, B.; Lebon, G.; Tate, C.G.; Weir, M.; Marshall, F.H.; Langmead, C.J. Pharmacology and structure of isolated conformations of the adenosine A(2)A receptor define ligand efficacy. Mol. Pharmacol. 2013, 83, 949-958. [CrossRef] [PubMed]

54. Klinger, M.; Kuhn, M.; Just, H.; Stefan, E.; Palmer, T.; Freissmuth, M.; Nanoff, C. Removal of the carboxy terminus of the A2A-adenosine receptor blunts constitutive activity: Differential effect on cAMP accumulation and MAP kinase stimulation. Naunyn Schmiedebergs Arch. Pharmacol. 2002, 366, 287-298. [CrossRef]

55. O'Malley, M.A. Expression, Purification, and Biophysical Characterization of G-Protein Coupled Receptors Expressed from Saccharomyces Cerevisiae. Ph.D. Thesis, University of Delaware, Delaware, Newark, 2009.

56. Mundell, S.; Kelly, E. Adenosine receptor desensitization and trafficking. Biochim. Biophys. Acta 2011, 1808, 1319-1328. [CrossRef]

57. Jain, A.R.; Britton, Z.T.; Markwalter, C.E.; Robinson, A.S. Improved ligand-binding- and signaling-competent human NK2R yields in yeast using a chimera with the rat NK2R C-terminus enable NK2R-G protein signaling platform. Protein Eng. Des. Sel. 2019, 32, 459-469. [CrossRef]

58. Jain, A.R.; Robinson, A.S. Functional Expression of Adenosine A3 Receptor in Yeast Utilizing a Chimera with the $\mathrm{A}_{2 \mathrm{~A}} \mathrm{R}$ C-Terminus. Int. J. Mol. Sci. 2020, 21, 4547. [CrossRef]

59. Yin, D.; Gavi, S.; Wang, H.Y.; Malbon, C.C. Probing receptor structure/function with chimeric G-protein-coupled receptors. Mol. Pharmacol. 2004, 65, 1323-1332. [CrossRef]

60. Tucker, A.L.; Jia, L.G.; Holeton, D.; Taylor, A.J.; Linden, J. Dominance of G(s) in doubly G(s)/G(i)-coupled chimaeric A(1)/A(2A) adenosine receptors in HEK-293 cells. Biochem. J. 2000, 352 Pt 1, 203-210. [CrossRef]

61. Dohlman, H.G.; Thorner, J.; Caron, M.G.; Lefkowitz, R.J. Model systems for the study of seven-transmembranesegment receptors. Annu. Rev. Biochem. 1991, 60, 653-688. [CrossRef]

62. Huang, X.P.; Karpiak, J.; Kroeze, W.K.; Zhu, H.; Chen, X.; Moy, S.S.; Saddoris, K.A.; Nikolova, V.D.; Farrell, M.S.; Wang, S.; et al. Allosteric ligands for the pharmacologically dark receptors GPR68 and GPR65. Nature 2015, 527, 477-483. [CrossRef] [PubMed]

63. King, K.; Dohlman, H.G.; Thorner, J.; Caron, M.G.; Lefkowitz, R.J. Control of yeast mating signal transduction by a mammalian beta 2-adrenergic receptor and Gs alpha subunit. Science 1990, 250, 121-123. [CrossRef] [PubMed]

64. Saito, H. Regulation of cross-talk in yeast MAPK signaling pathways. Curr. Opin. Microbiol. 2010, 13, 677-683. [CrossRef] [PubMed]

65. Chen, R.E.; Thorner, J. Function and regulation in MAPK signaling pathways: Lessons learned from the yeast Saccharomyces cerevisiae. Biochim. Biophys. Acta 2007, 1773, 1311-1340. [CrossRef] [PubMed]

66. Fowlkes, D.M.; Broach, J.R.; Manfredi, J.P.; Klein, C.A.; Murphy, A.J.M.; Paul, J.I.; Trueheart, J.S. Yeast cells expressing modified G proteins and methods of use therefor. United States Patent No. 7,105,309 B2, US. Patent Office, 2006.

67. Brown, A.J.; Dyos, S.L.; Whiteway, M.S.; White, J.H.; Watson, M.A.; Marzioch, M.; Clare, J.J.; Cousens, D.J.; Paddon, C.; Plumpton, C.; et al. Functional coupling of mammalian receptors to the yeast mating pathway using novel yeast/mammalian $\mathrm{G}$ protein alpha-subunit chimeras. Yeast 2000, 16, 11-22. [CrossRef]

68. Burke, D.; Dawson, D.; Stearns, T. Cold Spring Harbor Laboratory. In Methods in Yeast Genetics: A Cold Spring Harbor Laboratory Course Manual, 2000th ed.; Cold Spring Harbor Laboratory Press: Plainview, NY, USA, 2000.

69. Shaner, N.C.; Campbell, R.E.; Steinbach, P.A.; Giepmans, B.N.; Palmer, A.E.; Tsien, R.Y. Improved monomeric red, orange and yellow fluorescent proteins derived from Discosoma sp. red fluorescent protein. Nat. Biotechnol. 2004, 22, 1567-1572. [CrossRef]

70. Gietz, R.D.; Woods, R.A. Transformation of yeast by lithium acetate/single-stranded carrier DNA/polyethylene glycol method. Methods Enzymol. 2002, 350, 87-96.

71. Arnold, C.E.; Parekh, R.N.; Yang, W.; Wittrup, K.D. Leader peptide efficiency correlates with signal recognition particle dependence in Saccharomyces cerevisiae. Biotechnol. Bioeng. 1998, 59, 286-293. [CrossRef]

72. Young, C.L.; Raden, D.L.; Caplan, J.L.; Czymmek, K.J.; Robinson, A.S. Cassette series designed for live-cell imaging of proteins and high-resolution techniques in yeast. Yeast 2012, 29, 119-136. [CrossRef]

73. McGraw, C.; Yang, L.; Levental, I.; Lyman, E.; Robinson, A.S. Membrane cholesterol depletion reduces downstream signaling activity of the adenosine A2A receptor. Biochim. Biophys. Acta Biomembr. 2019, 1861, 760-767. [CrossRef]

74. Bitter, G.A.; Egan, K.M. Expression of interferon-gamma from hybrid yeast GPD promoters containing upstream regulatory sequences from the GAL1-GAL10 intergenic region. Gene 1988, 69, 193-207. [CrossRef] 
75. Niebauer, R.T.; Gao, Z.G.; Li, B.; Wess, J.; Jacobson, K.A. Signaling of the Human P2Y(1) Receptor Measured by a Yeast Growth Assay with Comparisons to Assays of Phospholipase C and Calcium Mobilization in 1321N1 Human Astrocytoma Cells. Purinergic Signal. 2005, 1, 241-247. [CrossRef] [PubMed]

76. Price, L.A.; Kajkowski, E.M.; Hadcock, J.R.; Ozenberger, B.A.; Pausch, M.H. Functional coupling of a mammalian somatostatin receptor to the yeast pheromone response pathway. Mol. Cell. Biol. 1995, 15, 6188-6195. [CrossRef] [PubMed]

77. Price, L.A.; Strnad, J.; Pausch, M.H.; Hadcock, J.R. Pharmacological characterization of the rat A2a adenosine receptor functionally coupled to the yeast pheromone response pathway. Mol. Pharmacol. 1996, 50, 829-837.

78. Hara, K.; Shigemori, T.; Kuroda, K.; Ueda, M. Membrane-displayed somatostatin activates somatostatin receptor subtype-2 heterologously produced in Saccharomyces cerevisiae. AMB Express 2012, 2, 63. [CrossRef]

79. Bertheleme, N.; Singh, S.; Dowell, S.J.; Hubbard, J.; Byrne, B. Loss of constitutive activity is correlated with increased thermostability of the human adenosine A2A receptor. Br. J. Pharmacol. 2013, 169, 988-998. [CrossRef]

80. Peeters, M.C.; Wisse, L.E.; Dinaj, A.; Vroling, B.; Vriend, G.; Ijzerman, A.P. The role of the second and third extracellular loops of the adenosine $\mathrm{A}_{1}$ receptor in activation and allosteric modulation. Biochem. Pharmacol. 2012, 84, 76-87. [CrossRef]

81. Magnani, F.; Shibata, Y.; Serrano-Vega, M.J.; Tate, C.G. Co-evolving stability and conformational homogeneity of the human adenosine A2a receptor. Proc. Natl. Acad. Sci. USA 2008, 105, 10744-10749. [CrossRef]

82. de Lera Ruiz, M.; Lim, Y.H.; Zheng, J. Adenosine A2A receptor as a drug discovery target. J. Med. Chem. 2014, 57, 3623-3650. [CrossRef]

83. Jespers, W.; Schiedel, A.C.; Heitman, L.H.; Cooke, R.M.; Kleene, L.; Van Westen, G.J.P.; Gloriam, D.E.; Müller, C.E.; Sotelo, E.; Gutiérrez-De-Terán, H. Structural Mapping of Adenosine Receptor Mutations: Ligand Binding and Signaling Mechanisms. Trends Pharmacol. Sci. 2018, 39, 75-89. [CrossRef]

84. McCusker, E.C. Overcoming Expression Obstacles in Producing Functional Components of the G-Protein Coupled Receptor Pathway; University of Delaware: Delaware, Newark, 2007.

85. Niebauer, R.T.; Robinson, A.S. Exceptional total and functional yields of the human adenosine (A2a) receptor expressed in the yeast Saccharomyces cerevisiae. Protein Expr. Purif. 2006, 46, 204-211. [CrossRef] [PubMed]

86. Niebauer, R.T.; Wedekind, A.; Robinson, A.S. Decreases in yeast expression yields of the human adenosine A2a receptor are a result of translational or post-translational events. Protein Expr. Purif. 2004, 37, 134-143. [CrossRef] [PubMed]

87. Wedekind, A.; O'Malley, M.A.; Niebauer, R.T.; Robinson, A.S. Optimization of the human adenosine A2a receptor yields in Saccharomyces cerevisiae. Biotechnol. Prog. 2006, 22, 1249-1255. [CrossRef] [PubMed]

88. Grisshammer, R.; Tate, C.G. Overexpression of integral membrane proteins for structural studies. Q. Rev. Biophys. 1995, 28, 315-422. [CrossRef] [PubMed]

89. Lohse, M.J.; Klotz, K.N.; Lindenborn-Fotinos, J.; Reddington, M.; Schwabe, U.; Olsson, R.A. 8-Cyclopentyl-1,3-dipropylxanthine (DPCPX)-a selective high affinity antagonist radioligand for $\mathrm{A}_{1}$ adenosine receptors. Naunyn-Schmiedebergs Arch. Pharmacol. 1987, 336, 204-210. [CrossRef] [PubMed]

90. Martens, D.; Lohse, M.J.; Rauch, B.; Schwabe, U. Pharmacological characterization of $A_{1}$ adenosine receptors in isolated rat ventricular myocytes. Naunyn-Schmiedebergs Arch. Pharmacol. 1987, 336, 342-348. [CrossRef]

91. Pankevych, H.; Korkhov, V.; Freissmuth, M.; Nanoff, C. Truncation of the $A_{1}$ adenosine receptor reveals distinct roles of the membrane-proximal carboxyl terminus in receptor folding and G protein coupling. J. Biol. Chem. 2003, 278, 30283-30293. [CrossRef]

92. Townsend-Nicholson, A.; Shine, J. Molecular cloning and characterisation of human brain $\mathrm{A}_{1}$ adenosine receptor cDNA. Brain Res. Mol. Brain Res. 1992, 16, 365-370. [CrossRef]

93. Stewart, G.D.; Valant, C.; Dowell, S.J.; Mijaljica, D.; Devenish, R.J.; Scammells, P.J.; Sexton, P.M.; Christopoulos, A. Determination of adenosine $\mathrm{A}_{1}$ receptor agonist and antagonist pharmacology using Saccharomyces cerevisiae: Implications for ligand screening and functional selectivity. J. Pharmacol. Exp. Ther. 2009, 331, 277-286. [CrossRef]

94. Knight, A.; Hemmings, J.L.; Winfield, I.; Leuenberger, M.; Frattini, E.; Frenguelli, B.G.; Dowell, S.J.; Lochner, M.; Ladds, G. Discovery of Novel Adenosine Receptor Agonists That Exhibit Subtype Selectivity. J. Med. Chem. 2016, 59, 947-964. [CrossRef]

95. Hsu, S.H.; Luo, C.W. Molecular dissection of G protein preference using Gsalpha chimeras reveals novel ligand signaling of GPCRs. Am. J. Physiol. Endocrinol. Metab. 2007, 293, E1021-E1029. [CrossRef] [PubMed] 
96. Conklin, B.R.; Farfel, Z.; Lustig, K.D.; Julius, D.; Bourne, H.R. Substitution of three amino acids switches receptor specificity of $\mathrm{Gq}$ alpha to that of Gi alpha. Nature 1993, 363, 274-276. [CrossRef] [PubMed]

97. Kostenis, E.; Waelbroeck, M.; Milligan, G. Techniques: Promiscuous Galpha proteins in basic research and drug discovery. Trends Pharmacol. Sci. 2005, 26, 595-602. [CrossRef] [PubMed]

98. Geppetti, P.; Veldhuis, N.A.; Lieu, T.; Bunnett, N.W. G Protein-Coupled Receptors: Dynamic Machines for Signaling Pain and Itch. Neuron 2015, 88, 635-649. [CrossRef] [PubMed]

99. O’Hayre, M.; Vazquez-Prado, J.; Kufareva, I.; Stawiski, E.W.; Handel, T.M.; Seshagiri, S.; Gutkind, J.S. The emerging mutational landscape of $\mathrm{G}$ proteins and G-protein-coupled receptors in cancer. Nat. Rev. Cancer 2013, 13, 412-424. [CrossRef] [PubMed]

100. Keuerleber, S.; Gsandtner, I.; Freissmuth, M. From cradle to twilight: The carboxyl terminus directs the fate of the A(2A)-adenosine receptor. Biochim. Biophys. Acta 2011, 1808, 1350-1357. [CrossRef]

Publisher's Note: MDPI stays neutral with regard to jurisdictional claims in published maps and institutional affiliations.

(C) 2020 by the authors. Licensee MDPI, Basel, Switzerland. This article is an open access article distributed under the terms and conditions of the Creative Commons Attribution (CC BY) license (http://creativecommons.org/licenses/by/4.0/). 